\title{
STERILIZATION OF MENTALLY RETARDED PERSONS: REPRODUCTIVE RIGHTS AND FAMILY PRIVACY
}

\author{
ElizABETh S. SCOTT*
}

Sterilization is one of the most frequently chosen forms of contraception in the world; ${ }^{1}$ many persons who do not want to have children select this simple, safe, and effective means of avoiding unwanted pregnancy. For individuals who are mentally disabled, however, sterilization has more ominous associations. Until recently, involuntary sterilization was used as a weapon of the state in the war against mental deficiency. Under eugenic sterilization laws in effect in many states, retarded persons were routinely sterilized without their consent or knowledge. ${ }^{2}$

* Associate Professor and Director, Center for the Study of Children and the Law, University of Virginia School of Law. J.D. 1977, University of Virginia.

My interest in the impact of the sterilization reform laws on families arose out of my association with the Forensic Psychiatry Clinic at the University of Virginia, an interdisciplinary clinic associated with the Law School and Medical School. This clinic has frequently conducted psychological evaluations of mentally disabled persons whose parents sought sterilization under Virginia's reform law. My observation of these individuals and their families has influenced my thinking on these issues. Several examples in this article are taken from Forensic Psychiatry Clinic cases.

I would like to thank my colleagues Kenneth Abraham, Richard Bonnie, Nancy Ehrenreich, Gary Melton, John Monahan, Gary Peller, and Walter Wadlington for their helpful comments on earlier drafts of this article. Special thanks are due to Robert Scott. I also thank Cathy Basham, John D'Amico, Margaret Rice, and Amy Nickell for research assistance.

1. See Isaacs, Reproductive Rights-1983: An International Survey, 14 Colum. Hum. RTs. L. REV. 311, 328 (1983) (90 to 100 million couples worldwide choose sterilization as a method of contraception). In the United States, sterilization is the most popular form of birth control for couples over thirty, and it rivals the Pill as a method of contraception for all couples. Id.

Salpingectomy (tubal ligation) is a surgical procedure by which the fallopian tubes are tied and severed. There are many different methods of performing tubal ligation, ranging from abdominal incisions to laparoscopy, a microsurgical procedure. See R. Hatcher, F. Guest, F. STEWART, G. Stewart, J. Trussell, S. Cerel \& W. Cates, Contraceptive Technology 1986-1987, at 283-93 (1986) [hereinafter CONTRACEPTIVE TECHNOLOGY]. Vasectomy, the most effective means of male fertility control, is a surgical excision of the vas deferens (a duct that carries sperm). Id. at 104, 281-83.

2. For a discussion of the eugenic sterilization movement of the early twentieth century, see infra notes 10-13 and accompanying text. See generally Lombardo, Three Generations, No Imbeciles, New Light on Buck v. Bell, 60 N.Y.U. L. Rev. 30, 31 (1985). It is estimated that almost 64,000 persons had been involuntarily sterilized under state eugenic sterilization laws by 1963 . The practice was most prevalent in California (20,108 sterilizations), Virginia (7162 sterilizations), and North Carolina (6297 sterilizations). Eugenic STERILIZATION app. at 1 (J. Robitscher ed. 1973). In Conservatorship of Valerie N., 40 Cal. 3d 143, 152, 707 P.2d 760, 765, 219 Cal. Rptr. 387, 392 (1985), the California Supreme Court noted that California led the nation in eugenic sterilization. This factor may have influenced the legislature's enactment of a law barring the sterilization of 
Sterilization law has undergone a radical transformation in recent years. ${ }^{3}$ Influenced by a distaste for eugenic sterilization and a desire to redress past injustices, the emerging law seeks to protect the interests of mentally disabled persons by erecting formidable barriers to sterilization. The policy goals of this reform movement are commendable. However, in its singleminded effort to prevent erroneous sterilizations, the law departs from what would be its underlying objectives: to protect where possible the individual's right to make her ${ }^{4}$ own reproductive decisions and to ensure that any decision made by others will best protect her interests.

Current law purports to protect the individual's reproductive rights, but the focus is one-sided. Although the law protects the "right to procreate," it does so by unnecessarily burdening the reciprocal right not to procreate. The option of sterilization-seen as a legitimate exercise of the right of reproductive privacy when chosen by the normal personmay be unavailable to the retarded person. Despite rhetorical emphasis on the importance of reproductive autonomy, the paternalistic stance of the law improperly limits the freedom of some persons who may be capable of making their own reproductive choices. In many states, only a court acting as decisionmaker is deemed capable of protecting disabled persons from those who would violate their rights.

The assumption that the law's overriding purpose is to protect the right to procreate arises from the historical and political context of the

incompetents. Cal. Prob. Code $§ 2356$ (d) (1981). This statutory provision was struck down in Valerie $N$.

3. The sterilization law reform movement is largely embodied in a series of judicial opinions beginning in 1980 with the Washington Supreme Court case of In re Guardianship of Hayes, 93 Wash. 2d 228, 239, 608 P.2d 635, 641 (1980). See infra notes 33-36 and accompanying text. See also Ruby v. Massey, 452 F. Supp. 361, 369 (D. Conn. 1978); In re C.D.M., 627 P.2d 607, 614 (Alaska 1981); Valerie N., 40 Cal. 3d at 160, 707 P.2d at 771-72, 219 Cal. Rptr. at 399; In re A.W., 637 P.2d 366, 370 (Colo. 1981); Wentzel v. Montgomery Gen. Hosp., Inc., 293 Md. 685, 703, 447 A.2d 1244, 1254 (1982), cert. denied, 459 U.S. 1147 (1983); In re Moe, 385 Mass. 555, 559, 432 N.E.2d 712, 716 (1982); In re Penny N., 120 N.H. 269, 271-72, 414 A.2d 541, 543 (1980); In re Grady, 85 N.J. 235, 258-62, 426 A.2d 467, 479-81 (1981); In re Sallmaier, 85 Misc. 2d 295, 297, 378 N.Y.S.2d 989, 991 (Sup. Ct. 1976); In re Terwilliger, 304 Pa. Super. 553, 564-68, 450 A.2d 1376, 1382-84 (1982); In re Guardianship of Eberhardy, 102 Wis. 2d 539, 578-79, 307 N.W.2d 881, 899 (1981). Several states have enacted reform statutes in recent years. See ConN. Gen. Stat. ANN. $\S 45-78 y(b)$ (West Supp. 1986); ME. Rev. Stat. ANN. tit. 34-B, §§ 7001-7017 (Supp. 1986); Or. Rev. Stat. § 436.305(3) (1983); Utah Code ANN. §64-10-8(4) (1986); VT. Stat. ANN. tit. 18, $\S 8705$ (Supp. 1986); VA. CODE ANN. $\S 54-325.10$ to .12 (1982). For a discussion of the reform laws, see infra notes 31-58 and accompanying text.

4. This article uses the feminine pronoun to refer to the mentally retarded person for whom sterilization is proposed because it appears that the issue arises much more frequently with females than with males. For example, all cases cited supra note 3 involved females. Furthermore, some of the analysis, such as that involving the intrusiveness of hysterectomy, applies only to females. Nonetheless, much of the analysis applies to both males and females. 
reform movement. It is not based on a careful analysis of the retarded person's interest in reproductive autonomy and how this interest may be affected by her disability. There is an understandable reluctance to undertake such analysis; even asking the question implies differences in the interests of retarded and nonretarded people. However, the failure to discern the actual interests at stake can lead to erroneous decisions contrary to the normative objective of the law.

This article focuses on parents' efforts to obtain sterilization of their mentally retarded children. As a result of the trend toward deinstitutionalization, a growing number of mentally disabled individuals live with their parents. Because current law reacts primarily to the state's historical wrongful treatment of institutionalized persons, ${ }^{5}$ it is not sufficiently responsive to the needs of retarded individuals who live with their families. ${ }^{6}$

Part I of the article describes the current law and explores how its paternalistic approach fails to protect the interests of mentally disabled persons when their parents propose sterilization. ${ }^{7}$ Part II develops an alternative approach, which I will call the "autonomy model." 8 This model is developed primarily through an analysis of the effects of mental disability on three dimensions of the disabled person's reproductive interest-avoiding unwanted pregnancy, having children, and making autonomous choices. Part III explores the implications of the autonomy model for the formulation of an optimal sterilization rule. ${ }^{9}$ The model suggests that the law should maximize individual and family autonomy and minimize paternalistic intervention by the state. The goal of protecting the retarded person's interests is largely achieved by choosing the appropriate decisionmaker; in most cases this will be the individual herself or her parents. Under this approach, the court's role in most cases is limited to deciding whether the individual has the capacity to make her own choices or whether her parents must make the decision for her.

5. Many eugenic sterilization laws, directed toward institutionalized patients, authorized the director of such facilities to make the decision or to petition a court. In Ruby v. Massey, $452 \mathrm{~F}$. Supp. 361 (D. Conn. 1978), a Connecticut law that permitted sterilization only of mentally disabled individuals in institutions was struck down on equal protection grounds. Id. at 367-69. Some laws required sterilization as a precondition to release from state institutions. See, e.g., Buck v. Bell, 274 U.S. 200, 204 (1927).

6. Indeed, most of the judicial opinions developing the paternalism model involved efforts by a parent or guardian to sterilize a child cared for at home. See, e.g., In re Grady, 85 N.J. 235, 240-42, 251, 426 A.2d 467, 469-70, 475 (1981); In re Sallmaier, 85 Misc. 2d 295, 296-97, 378 N.Y.S.2d 989, 989-90 (Sup. Ct. 1976).

7. See infra notes 10-61 and accompanying text.

8. See infra notes $62-139$ and accompanying text.

9. See infra notes $140-80$ and accompanying text. 


\section{Current Sterilization law: A Paternalism Model}

\section{A. The Context of Reform.}

Three factors have stimulated and shaped the reform of sterilization law: the discrediting of the eugenic theory, the development of the constitutional doctrine of reproductive privacy, and the changing conception of mental retardation. The vigilant stance of current law is largely a response to the unsavory history of eugenic sterilization in this country. ${ }^{10}$ During the first half of this century, laws in many states authorized sterilization of mentally deficient persons and others believed to be societal burdens. ${ }^{11}$ These laws were based largely on eugenic theory, which enjoyed considerable popularity in the progressive era. The theory posited that intelligence and most personality traits are genetically based and are predictably inherited by children from their parents. ${ }^{12}$ The objective of

10. See In re Moe, 385 Mass. 555, 559, 432 N.E.2d 712, 717 (1982) ("We are well aware of the sordid history of compulsory eugenic sterilization laws in the United States."); Grady, 85 N.J. at 245,426 A.2d at 472 ("[W]e have serious doubts about the scientific validity of eugenic sterilization."); In re Guardianship of Hayes, 93 Wash. 2d 228, 236, 608 P.2d 635, 640 (1980) (“[T]he theoretical foundation for eugenic sterilization as a method of improving society has been disproved."). Rejection of compulsory sterilization laws on scientific and social policy grounds has had broad support in the legal literature since the 1960's. See Burgdorf \& Burgdorf, The Wicked Witch is Almost Dead: Buck v. Bell and the Sterilization of Handicapped Persons, 50 TEMP. L.Q. 995, 1033-34 (1977); Ferster, Eliminating the Unfit-Is Sterilization the Answer?, 27 OHIO ST. L.J. 591, 619-25 (1966); Murdock, Sterilization of the Retarded: A Problem or a Solution?, 62 CALIF. L. Rev. 917, 934-35 (1974); Sherlock \& Sherlock, Sterilizing the Retarded: Constitutional, Statutory, and Policy Alternatives, 60 N.C.L. REv. 943, 980-83 (1982).

11. Sterilization laws were directed at the mentally retarded, mentally ill, epileptic, and criminal populations. Indiana passed the first involuntary sterilization law in 1907. Act of March 9, 1907, ch. 215, 1907 IND. ACTS 377 (repealed 1963). By 1925, twenty-three states had passed eugenic sterilization laws. Cynkar, Buck v. Bell: "Felt Necessities" v. Fundamental Values?, 81 Colum. L. REv. 1418, 1433 (1981). As late as 1966, twenty-six states had eugenic sterilization laws. Ferster, supra note 10, at 596. State courts often upheld sterilization laws using two police power justifications-that of preventing the birth of defective children and that of lowering the public welfare expense of supporting children whose parents could not support them. See In re Simpson, 180 N.E.2d 206, 208 (Ohio P. Ct. 1962); Ferster, supra note 10, at 609.

Some sterilization laws were used to punish habitual criminals and rapists. A Washington statute authorizing the sterilization of convicted rapists was upheld in State v. Feilen, 70 Wash. 65, 66, 126 P. 75, 76 (1912). The United States Supreme Court, however, struck down an Oklahoma statute allowing sterilization of habitual criminals in Skinner v. Oklahoma ex rel. Williamson, 316 U.S. 535, 542-43 (1942). Some statutes had paternalistic objectives and authorized sterilization if it was in the best interest of the individual and society. Virginia's sterilization statute was enacted in part to alleviate fears that institutionalized individuals returning to society would produce children. See Act of March 20, 1924, ch. 394, 1924 VA. ACTS 569, 569 (amended and recodified 1968).

12. The eugenic movement was an outgrowth of Mendelian genetics. The eugenicists, building upon Mendel's findings about the hereditability of physical traits, argued that intelligence, personality, and even character traits such as dishonesty, criminality, and laziness were directly "transmitted." See H. Laughion, Eugenic Sterilization in the United States 369 (1922). Furthermore, certain traits were associated with racial or national groups. Id. at 372-92 (listing "human traits which have been shown to follow definite rules of inheritance"). This view served as the basis for the Nazi eugenic policies. The accepted view was that defectives were reproducing 


\section{the eugenic sterilization laws was to protect and improve society by preventing reproduction by those who might produce defective off- spring. ${ }^{13}$}

In 1927, the Supreme Court in Buck v. Bell ${ }^{14}$ upheld Virginia's ster-

more quickly than normal people, thus posing a significant threat to society. For an excellent historical account of the eugenic movement, see Cynkar, supra note 11, at 1420-35.

13. See H. LaUghlin, supra note 12, at 369 ("[D]efectives who are practically certain to breed principally defectives, owe a debt to the community that can be discharged only by an adequate guarantee that they shall not contribute to the next generation."). The following quote reveals the threat to society that eugenicists thought the mentally retarded posed:

The past few years have witnessed a striking awakening of professional and popular consciousness of the widespread prevalence of feeblemindedness and its influence as a source of wretchedness to the patient himself and to his family, and as a causative factor in the production of crime, prostitution, pauperism, illegitimacy, intemperance, and other complex social diseases. ... The feebleminded are a parasitic, predatory class, never capable of self-support or of managing their own affairs. ... They cause unutterable sorrow at home and are a menace and danger to the community. . . . Feebleminded women are almost invariably immoral and if at large usually become carriers of venereal disease or give birth to children who are as defective as themselves.... Every feebleminded person, especially the high-grade imbecile, is a potential criminal, needing only the proper environment and opportunity for the development and expression of his criminal tendencies.

S. Davies, Social Control of the Feebleminded 56 (1923), quoted in Cynkar, supra note 11, at $1424-25$.

A 1934 law review note, arguing for a sterilization law in Kentucky, also reflects this perception of societal threat: "Since time immemorial, the criminal and defective have been the "cancer of society.' Strong, intelligent, useful families are becoming smaller and smaller; while irresponsible, diseased, defective families are becoming larger. The result can only be race degeneration." Note, $A$ Sterilization Statute for Kentucky?, 23 KY. L.J. 168, 168 (1934), quoted in Burgdorf \& Burgdorf, supra note 10 , at 998 .

14. 274 U.S. 200, 207 (1927). Prior to Buck v. Bell, most courts struck down sterilization statutes as unconstitutional. See Davis v. Berry, 216 F. 413, 417 (S.D. Iowa 1914) (cruel and unusual punishment grounds), rev'd as moot, 242 U.S. 468 (1917); Williams v. Smith, 190 Ind. 526, 528, 131 N.E. 2, 2 (1921) (due process grounds); Haynes v. Lapeer, 201 Mich. 138, 145, 166 N.W. 938, 941 (1918) (equal protection grounds); see also Burgdorf \& Burgdorf, supra note 10, at 1000-01 nn.44-48; Ferster, supra note 10, at 593-94 nn.11-12.

Buck v. Bell is often cited to illustrate the abuses of eugenic sterilization policy. Bell was the test case for Virginia's new sterilization law. Carrie Buck was a 17 year-old girl who had been committed to a state institution for the epileptic and feebleminded after giving birth to an illegitimate daughter. The Virginia law required that institutionalized patients be sterilized for eugenic and therapeutic reasons as a condition of release. See Cynkar, supra note 11, at 1437-38. Subsequent historical research has suggested that neither Carrie, her mother, nor Carrie's daughter (who was an infant at the time of the "diagnosis") were "imbeciles" as characterized by Justice Holmes in his much quoted proclamation, "[t]hree generations of imbeciles are enough." Bell, 274 U.S. at 207. Indeed, it has been reported that Carrie's daughter was on the second grade honor roll before dying at age eight. See Lombardo, supra note 2 , at 61 . It seems probable that the moralistic impulses of the eugenicists influenced the categorization of this family as feebleminded. See Cynkar, supra note 11, at 52-53. Carrie and her mother both produced children out of wedlock. The testimony of Dr. Priddy, the director of the institution, also suggests that sterilization was viewed as a way to achieve social control over the poor: "[T]hese people belong to the shiftless, ignorant, and worthless class of anti-social whites of the South ... [about whom] it is impossible to get intelligent and satisfactory data ...." Lombardo, supra note 2, at 51-52. See also Cynkar, supra note 11, at 1439 (discussing use of sterilization as method for controlling poverty).

This harsh tone may obscure the fact that eugenic policies were not viewed as oppressive infringements on individual rights, but as tools of social reform. Eugenicists attributed most social 
ilization law against constitutional challenge and implicitly accepted the validity of eugenic theory. Even at that time, however, the scientific merit of the theory was controversial; ${ }^{15}$ it has since been largely discredited. ${ }^{16}$ Reports of widespread sterilization in Nazi Germany led to increased criticism of eugenic sterilization laws. By the 1960's, involuntary sterilization was frequently characterized as an unjustified intrusion by the state on individual liberty and privacy. ${ }^{17}$ The reform law that has

problems to heredity; they linked crime, prostitution, and poverty to mental deficiency. Progressives therefore embraced these policies as state action designed to improve society, arguing that if afflicted individuals were prevented from reproducing, society's ills would disappear. Justice Holmes was articulating the accepted liberal view in endorsing the eugenic rationale.

15. See Cynkar, supra note 11, at 1420-35. It appears, though, that Buck's attorney, Whitehead, never fully briefed this issue for argument before the Court. It was only in the petition for rehearing (following a storm of public protest over Holmes's opinion) that Whitehead included the strongest arguments against the sterilization law-questioning for the first time the "scientific" propositions espoused by eugenic theories. Some have pointed to this sequence of events to support the allegation that Bell was a "friendly suit." Lombardo, supra note 2, at 57.

16. Researchers in genetics increasingly disassociated themselves from the eugenic movement as scientific understanding of genetics became more sophisticated in the 1920's and 1930's. In 1936, the American Neurological Association Committee for the Investigation of Eugenical Sterilization issued a statement opposing eugenic sterilization and challenging its scientific premises. See Ferster, supra note 10, at 602-03. In 1937, a committee of the American Medical Association also adopted this position. Id. at 603 . The critical scientific fallacy underlying the sterilization laws is that "conditions such as feeblemindedness lump together cases having no genetic component with those in which there may be a partial or complete genetic contribution." Moorhead, Views of a Geneticist on Eugenic Sterilization, in EUgENIC STERILIZATION, supra note 2, at 115. For an interesting history of the eugenics movement, see Kevles, The Annals of Eugenics, New YorKer, Oct. 8, 1984, at 51; Oct. 15, 1984, at 52; Oct. 22, 1984, at 92; Oct. 29, 1984, at 51.

This is not to say that intelligence does not have a hereditary component. Most modern experts agree that genetic factors significantly influence intelligence and that there is, in general, a relationship between children's and parents' intelligence. Scarr-Salapatek, Genetics and the Development of Intelligence, 4 CHILD DEv. Res. 1 (1975). Psychological studies indicate that both heredity and environment can influence intelligence. The most impressive evidence for some genetic determination of intelligence comes from studies of adopted children. Professor Munzinger critically evaluated studies of adopted children and found that five studies (involving 351 families) showed that the average correlation between the parents' and their adopted children's IQs was 0.19. B. MARTIN, ABNORMal Psychology 567 (1977). He found a significantly greater correlation between the intelligence level of the same children and their biological parents. Id.

17. The development of the doctrine of reproductive privacy in the 1960's and 1970's has affected the constitutional analysis of sterilization laws. Since eugenic sterilization laws infringe a fundamental right, these laws are subject to strict scrutiny rather than the rational-basis review engaged in by Justice Holmes in Bell. See Roe v. Wade, 410 U.S. 113, 155 (1973); Skinner v. Oklahoma ex rel. Williamson, 316 U.S. 535, 541 (1942). The Virginia statute in Bell probably would not meet this heightened scrutiny given the dubious validity of eugenic theory. Indeed, several courts authorizing parens patriae sterilization have assumed that Bell is constitutionally suspect. See In re A.W., 637 P.2d 366, 368 (Colo. 1981); In re Grady, 85 N.J. 235, 246, 426 A.2d 467, 472 (1981).

Even if the state could establish that involuntary sterilization was necessary to promote a compelling state interest, the statute in Bell might fall under the "least restrictive alternative" doctrine. In Shelton v. Tucker, 364 U.S. 479 (1960), the Supreme Court stated this doctrine as follows: "Even though the governmental purpose be legitimate and substantial, that purpose cannot be pursued by means that broadly stifle fundamental personal liberties when the end can be more narrowly 
emerged in recent years represents a vehement rejection of the philosophy and policy of the eugenic movement. ${ }^{18}$ It is explicitly designed to protect the interests of the retarded person rather than those of society.

A second impetus to reform has been the development of the constitutional doctrine of reproductive privacy. ${ }^{19}$ A principal reason why courts and legislatures have been concerned about protecting the reproductive rights of retarded persons ${ }^{20}$ is that reproductive rights in general

achieved. The breadth of legislative abridgment must be viewed in the light of less drastic means for achieving the same basic purpose." Id. at 488 (footnote omitted). See generally Hoffmann \& Faust, Least Restrictive Treatment of the Mentally Ill: A Doctrine in Search of Its Senses, 14 SAN DiEgo L. REV. 1100 (1977).

Numerous commentators have criticized eugenic sterilization and Justice Holmes's opinion in Bell from a constitutional perspective. See Sherlock \& Sherlock, supra note 10, at 954; Zenoff, Reappraisal of Eugenic Sterilization Laws, 10 Clev.-Marshall L. Rev. 149, $159-60$ (1961); Note, Eugenic Sterilization Statutes: A Constitutional Re-Evaluation, 14 J. FAM. L. 280, 297 (1975).

18. Twenty-eight eugenic sterilization statutes were reported in 1956. See O'Hara \& Sanks, Eugenic Sterilization, 45 GEO. L.J. 20, 42 (1956). Many of these have been repealed since the 1960's. See Cal. Welf. \& InSt. Code $§ 7254$ (West Supp. 1972) (repealed 1972); Me. Rev. Stat. ANN. tit. 34, § 2462 (1978) (repealed 1981); OKLA. Stat. ANN. tit. 43A, § 341 (West 1979) (repealed 1983). Today only a few states have police-power sterilization laws. See Miss. CoDE ANN. $\S 41-45-$ 1 (1972); N.C. GeN. STAT. § 35-36 (1984); S.C. Code ANN. § 44-47-10 (Law. Co-op. 1976); W. VA. CODE $§ 27-16-1$ (1980).

19. A series of Supreme Court opinions beginning with Griswold v. Connecticut, 381 U.S. 479, 485 (1965) (striking down law banning use of contraceptives), developed the modern doctrine of reproductive privacy. Several decisions have struck down restrictions on the use and sale of contraceptives and on a woman's right to choose abortion. See, e.g., Thornburgh v. American College of Obstetricians \& Gynecologists, 106 S. Ct. 2169, 2182 (1986) (women have constitutionally protected right to abortion; state regulation may not intimidate women into continuing pregnancies); City of Akron v. Akron Center for Reproductive Health, Inc., 462 U.S. 416, 452 (1983) (city cannot impose restrictive requirements on abortion or determine that all minors under age 15 are too immature to make abortion decision); Bellotti v. Baird, 443 U.S. 622, 651 (1979) (plurality opinion) (mature minors have right to make abortion decisions without parental consent); Carey v. Population Servs. Int'l, 431 U.S. 678, 694 (1977) (law prohibiting sale of contraceptives to anyone under age 16 restricts reproductive privacy); Planned Parenthood v. Danforth, 428 U.S. 52, $69-70$ (1976) (states cannot give husband or parents veto over wife's or daughter's abortion decision by requiring consent); Roe, 410 U.S. at 164-66 (women have right to terminate pregnancy through abortion until viability); Doe v. Bolton, 410 U.S. 179, 201 (1973) (requirement that abortions be performed in hospitals and approved by a hospital committee unduly restricts reproductive privacy); Eisenstadt v. Baird, 405 U.S. 438, 443 (1972) (making contraceptives unavailable to single women infringes reproductive privacy).

Aside from the uncertain scientific basis of eugenic theories, there has been a vehement rejection on ethical grounds of the policy that less intelligent members of society should not be allowed to reproduce.

20. The judicial opinions dealing with parens patriae sterilization repeatedly emphasize the importance of protecting the retarded person's constitutional right of reproductive privacy. See Conservatorship of Valerie N., 40 Cal. 3d 143, 161, 707 P.2d 760, 772, 219 Cal. Rptr. 387, 399 (1985) (incompetent women have procreative choice that is recognized as fundamental right); see also In re Moe, 385 Mass. 555, 563-64, 432 N.E.2d 712, 719 (1982) (decision to bear child at heart of constitutionally protected right to privacy); Grady, 85 N.J. at 250,426 A.2d at 474 (inability to make reproductive decisions should not result in forfeiture of constitutional right); In re Guardianship of Hayes, 93 Wash. 2d 228, 234, 608 P.2d 635, 639 (1980) (sterilization implicates right to privacy and fundamental right to procreate). 
have been accorded a special status in recent years. The right of normal adults and mature minors ${ }^{21}$ to avoid unwanted pregnancy through abortion, contraception, and (for adults) sterilization ${ }^{22}$ is well established. The right to procreate, in contrast, has received little attention, probably because it has seldom been challenged. ${ }^{23}$ The development of the doctrine of reproductive privacy casts substantial doubt on the continued validity of involuntary sterilization laws like the one upheld in Buck v. Bell. ${ }^{24}$ There is general consensus that mentally disabled persons should, to the extent that their disability allows, enjoy the same right of reproductive privacy as normal people. ${ }^{25}$

21. See supra note 19.

22. The Supreme Court has not addressed the issue of the right of normal adults to obtain sterilization. Lower courts, however, have expanded the right of reproductive privacy to include the right to obtain sterilization. See Hathaway v. Worcester City Hosp., 475 F.2d 701, 706 (1st Cir. 1973) (hospital policy banning sterilization violates equal protection clause because surgical procedures of equal risk are permitted); Ponter v. Ponter, 135 N.J. Super. 50, 55, 342 A.2d 574, 577 (1975) (married woman has constitutional right to obtain sterilization without husband's consent).

Normal minors are generally not permitted to obtain sterilization. See, e.g., Colo. REv. STAT. $\S$ 27-10.5-128(1) (1982); VT. STAT. ANN. tit. 18, § 8705(a) (Supp. 1986). The enormous cost of error justifies some restriction on reproductive autonomy. Unlike abortion and contraception, the minor can postpone the sterilization decision with minimal cost.

23. See Robertson, Procreative Liberty and the Control of Conception, Pregnancy, and Childbirth, 69 VA. L. REV. 405, 406 (1983). Professor Robertson provides a comprehensive analysis of the right to procreate in the context of modern reproductive technology. He defines three dimensions of the right-conception, gestation and birth, and rearing.

The only Supreme Court decision that specifically affirms the right to procreate is Skinner v. Oklahoma ex rel. Williamson, 316 U.S. 535 (1942). The Court did not analyze the substance of the right but described it as essential to the "survival of the race." $I d$. at 541.

24. Nonetheless, constitutional analysis of the reform law is complicated by two factors. The application of the doctrine of reproductive privacy to persons with questionable capacity for autonomous decisionmaking is unclear to the extent that the right of reproductive privacy is the right to control reproductive decisions. Furthermore, unlike eugenic law, the reform law is designed to promote the mentally retarded person's interest (by making the option of sterilization available); it is not inherently an infringement by the state on a fundamental right. As noted above, the right to choose sterilization is itself constitutionally protected. See supra note 22. Thus the application of strict scrutiny is unclear.

25. Reform advocates tend to define the retarded person's interest in reproductive privacy solely in terms of the right to procreate. In Foy v. Greenblott, 141 Cal. App. 3d 1, 9-10, 190 Cal. Rptr. 84, 90 (1983), a severely retarded woman became pregnant and had a child. She sued her conservator for negligence in failing to prevent the pregnancy and birth through contraception or abortion. The court rejected the claim on the ground that her conservator would have interfered with her right of reproductive privacy by taking such measures. Id. at 9, 190 Cal. Rptr. at 89-90.

Many courts that have examined sterilization laws have likewise emphasized the disabled woman's fundamental right to procreate. See In re Truesdell, 63 N.C. App. 258, 267, 304 S.E.2d 793, 799 (1983) ("'S]terilization not only affects the individual's fundamental right to procreate, . . it forever deprives the individual of that basic liberty."). In Conservatorship of Valerie N., 40 Cal. 3d 143, 707 P.2d 760, 219 Cal. Rptr. 387 (1985), Chief Justice Bird, dissenting, argued to uphold California's statutory ban on the sterilization of individuals under a conservatorship on the grounds of the right to procreate. Id., at 183, 707 P.2d at 788, 219 Cal. Rptr. at 415 (Bird, C.J., dissenting). Bird argued that the mentally disabled person does not have the right to be sterilized because that right is premised on the ability to make a decision. Id. According to Bird, the mentally disabled 
The view that the mentally retarded person should exercise her rights to the fullest extent possible reflects a changing conception of mental retardation. A cognitive developmental approach has to some extent supplanted the medical model of mental retardation that emphasizes unalterable organic brain pathology. ${ }^{26}$ With the application of cognitive developmental theory to the functioning of mentally retarded persons, there has been a corresponding appreciation that the designation "mentally retarded" applies to individuals who exhibit a broad range of deficiencies. ${ }^{27}$

person does have an unrestricted right to procreate, because she has the right to retain "the biological capabilities with which ... she was born into this world." Id. at 181, 707 P.2d at 786, 219 Cal. Rptr. at 413. See generally Price \& Burt, Sterilization, State Action and the Concept of Consent, $1 \mathrm{~L}$. \& Psychology Rev. 57, 63-65 (1975) (characterizing third-party consent to sterilization as a deprivation of the individual's rights).

Some laws assume that the retarded person's interest in reproductive choice is like that of the normal person, and that the law's role is to remove the barrier created by her disability. The New Jersey Supreme Court articulated this view: "Lee Ann does not have the ability to make a choice between sterilization and procreation. ... But her inability should not result in the forfeit of this constitutional interest. . . . [T] he decision . . 'should not be discarded solely on the basis that her condition prevents her conscious exercise of the choice.' "In re Grady, 85 N.J. 235, 250, 426 A.2d 467, 474 (1981) (quoting In re Quinlan, 70 N.J. 10, 41, 355 A.2d 647, 664, cert. denied, 429 U.S. 922 (1976)).

26. See E. Schulman, Focus on the Retarded Adult: Programs and Services 34-94 (1980). Schulman traces the historical development of conceptions of mental disability and corresponding public policy responses. The medical model of retardation dominated in the late nineteenth and early twentieth centuries. This model described and classified several organic causes of retardation including brain injury and chromosomal and genetic abnormalities such as Down's Syndrome, Tay Sachs disease, microcephaly, and hydrocephaly. The medical approach is useful in understanding severe retardation; persons with Wechsler IQs below 39 are almost always in the organically impaired category. See R. Macklin \& W. Gaylin, Mental Retardation and STERILIZATION 13-14 (1981). But organic pathology does not explain the causes of disability in most mildly retarded persons; only $25 \%$ of mildly retarded persons are organically impaired. The remaining $75 \%$ may simply be comprised of individuals whose intelligence level is at the lower end of a continuum. See E. Schulman, supra, at 55. But see B. MarTiN, supra note 16, at 570-74 (describing the extent to which mild retardation has organic causes).

Professor Zigler and others developed the cognitive developmental approach that applies Piaget's theories to the functioning of mentally retarded persons. See Zigler, Mental Retardation: Current Issues and Approaches, 2 REv. ChILd Dev. Res. 107, 111-13 (1966). Piaget postulated that human intelligence developed in a series of adaptive stages occurring in childhood and adolescence. See H. Kaplan \& B. Sadock, Modern Synopsis of Comprehensive Textbook of PsychiaTRY 57 (3d ed. 1981). Disabled persons progress through the developmental stages at a slower rate than normal children and fail to attain the higher developmental stages. The stage of cognitive development attained correlates with the level of mental retardation. See id. at 852.

27. A retarded person is classified by comparing her behavior to a particular age group's behavior using factors such as academic skill, social responsiveness, responsibility, and vocational performance. The classification may change as the retarded person develops or as societv's expectations change. See H. Kaplan \& B. SADOcK, supra note 26, at 853 . Four commonly used classifications of mental retardation have been recognized by the American Psychiatric Association's Diagnostic and Statistic Manual of Mental Disorders. See id. at 851. These classifications are based on the Weschler Intelligence Quotient of the affected person. The four classifications are: 
Custodial programs that segregate and warehouse retarded persons are no longer endorsed by professionals. Today, programs for mentally retarded persons pursue the goal of "normalization"-the development of skills that enable the individual to live as independently and self-sufficiently as possible. ${ }^{28}$ Issues of sexual autonomy are an important aspect

(1) Mild-IQ 51 to 70 . Mildly retarded individuals can usually master basic academic skills. Adults are capable of living independently or semi-independently in the community. See id. at 852 . Mildly retarded persons may need slight assistance such as health care reminders or help in purchasing clothes. They are coordinated, can navigate their neighborhood, can communicate and understand complex verbal concepts, and can perform semi-skilled or low skill jobs. See H. Grossman, Classification in Mental Retardation (1983). Mildly retarded individuals handle sexual impulses and urges normally and can develop appropriate adaptive skills through education. See R. Monat, Sexuality and the Mentally Retarded 6 (1982).

(2) Moderate-IQ 36 to 50. Many individuals functioning at this level can learn self-help, communication, social, and simple occupational skills, but only limited academic or vocational skills. See H. KAPLAN \& B. SADOCK, supra note 26, at 852 . Moderately retarded persons perform personal hygiene tasks, possess gross and fine motor coordination, use complex sentences, and read simple prose material; they may initiate activities and conscientiously perform simple household tasks. See id. Moderately retarded persons can learn sexual responsibility, but self-experimentation is common. See R. MonAT, supra, at 15.

(3) Severe-IQ 20 to 35 . Severely retarded persons require continuing and close supervision, but may perform self-help and simple work tasks. See H. KAPLAN \& B. SADOcK, supra note 26, at 851-52. They can usually prepare simple foods and perform uncomplicated household tasks. Severely retarded persons may use sentences and understand verbal communication, but they profit most from systematic habit training. See id. They do not control sexual impulses well but conditioning can alter their behavior to some extent. There is a limited ability to predict or foresee the consequences of their sexual behavior. See R. Monat, supra, at 3-4.

(4) Profound-IQ 0 to 20. Profoundly retarded persons require continuing and close supervision, but some may be able to perform simple self-help tasks. They often have handicaps and require total life-support systems. See H. Kaplan \& B. SADock, supra note 26, at 851-52. Profoundly retarded persons do not perform all personal hygiene tasks and generally use only simple language. See id. Their sexual reactions are predominantly impulsive, they cannot easily engage in sexual activity on a reciprocal level, and they often masturbate in a harmful or excessive way. See $\mathbf{R}$. MONAT, supra, at 4, 24-25.

28. Professor Nirje is the leading proponent of normalization. He defined the concept as "making available to the mentally subnormal patterns and conditions of everyday life which are as close as possible to the norms and patterns of the mainstream of society." Nirje, Symposium on "Normalization": The Normalization Principle-Implications and Comments, 16 Brit. J. MENTAL SubnorMALITY 62, 62 (1970). See also Wolfensburger, The Principle of Normalization and Its Implication to Psychiatric Services, 127 AM. J. Psychiatry 291, 291-97 (1970). Normalization has become the primary objective of programs for the retarded.

The two central components of normalization are deinstitutionalization and educational mainstreaming. Experts generally agree that mentally retarded persons attain fuller development in community settings rather than in institutions. Retarded children develop better when they live with their families and are reared by their parents. Adults may also thrive in a well-functioning family; however, a residence for retarded adults may alternatively provide companionship and support. See E. SChulman, supra note 26 , at 256-83.

The normalization approach also emphasizes educational mainstreaming. The federal law dealing with the education of handicapped individuals supports this normalization principle. See 20 U.S.C. $\S 1412(5)$ (1982) (state must provide "procedures to assure that, to the maximum extent appropriate, handicapped children ... are educated with children who are not handicapped"). 


\section{of the normalization trend; ${ }^{29}$ freedom and privacy in social and sexual} relationships may be as important to mentally disabled persons as to others. Furthermore, marriage and parenthood are realistic options for some mildly disabled persons who, with appropriate training, may be capable of fulfilling those roles. ${ }^{30}$ Sterilization is viewed as rarely desirable because many mentally retarded persons are presumed to have at least a potential interest in having children.

Many mildly retarded persons have been "mainstreamed" into regular classrooms. See E. SCHULMAN, supra note 26, at 65 .

Implicit in the concept of normalization is the notion that mentally retarded persons should enjoy the same legal rights as others to the extent that they are able to do so. In an official statement in 1973, the American Academy of Mental Deficiency emphasized that "[m]entally retarded citizens are entitled to enjoy and exercise the same rights as are available to nonretarded citizens, to the limits of their ability to do so." Rights of Mentally Retarded Persons: An Official Statement of the American Academy of Mental Deficiency, Mental Retardation, Oct. 1973, at 56, 56-57. See also Wald, Basic Personal and Civil Rights, in The President's Committee on Mental Retardation, The Mentally Retarded Citizen and the Law 3 (1976).

Some commentators argue that zealous commitment to the principle of normalization in education may not help seriously impaired persons because the quality of the individual's educational experience depends on factors other than physical placement. See, e.g., Vitello, Cautions on the Road to Normalization, Mental Retardation, Oct. 1974, at 39, 40.

29. The notion that mentally disabled persons are sexual beings is only recently gaining acceptance among professionals who work with this population. In the past, dealing with sexual behavior was viewed as a "problem"; usually, preventing sexual contact among residents or participants in programs/placements for mentally retarded persons was standard policy. Mentally retarded persons have traditionally been deemed incapable of controlling sexual impulses, a view that is clearly erroneous as applied to mildly retarded persons. See E. Schulman, supra note 26, at 298. Today, as part of the normalization trend, sex education is an important part of programs for mentally retarded persons. Helping the individual deal with sexual issues in a positive and socially appropriate manner has become the objective of many programs. See S. HaArix \& K. Menninger, Sexuality, Law, and the Developmentally Disabled Person 151 (1981); R. Monat, supra note 27 , at $46-49$; E. SChUlman, supra note 26 , at 292-312.

30. Historically, many states have statutorily prohibited or restricted marriage by mentally retarded persons. See Note, The Right of the Mentally Disabled to Marry: A Statutory Evaluation, 15 J. FAM. L. 463, 487-507 (1977). States have begun to repeal these statutes because of a growing awareness that some mentally retarded persons may successfully marry and rear children. See Shaman, Persons Who Are Mentally Retarded: Their Right to Marry and Have Children, 12 FAM. L.Q. 61, 84 (1978); Note, Retarded Parents in Neglect Proceedings: The Erroneous Assumption of Parental Inadequacy, 31 STAN. L. REV. 785, 804 (1979).

Mental retardation professionals generally support normalization; however, many are still concerned about the capability of mentally retarded persons to be parents. Indeed, one goal among professionals has been to promote normal relationships that are not burdened by the possibility of pregnancy. See E. Schulman, supra note 26, at 301-03. There is growing recognition, however, that some mentally disabled persons can function as parents. See Rosenberg \& McTate, Intellectually Handicapped Mothers: Problems and Perspectives, Children Today, Jan.-Feb. 1982, at 24. Authorities seem to require that mentally retarded parents provide a higher standard of care than that generally expected of normal parents. See Murphy, Coleman \& Abel, Human Sexuality in the Mentally Retarded, in TREATMENT Issues AND InNOVATIONS IN MENTAL RETARDATION 614 (J. Matson \& F. Andrasik eds. 1983). Recently there has been a focus on supportive services and training in parenting skills for mentally retarded persons. See Madsen, Parenting Classes for the Mentally Retarded, 17 Mental Retardation 195, 195 (1979); Rosenberg \& McTate, supra, at 24. 


\section{B. Current Sterilization Law.}

The preceding factors have stimulated the reform of sterilization law in recent years. A few jurisdictions have banned sterilization of incompetent persons altogether. ${ }^{31}$ Under most reform laws, however, the state may authorize sterilization under its parens patriae authority if certain conditions are met. ${ }^{32}$ Many of these laws follow a model derived from a Washington Supreme Court case, In re Guardianship of Hayes. ${ }^{33}$ Hayes requires a two-part inquiry. First, the court must determine whether the individual is competent to make an informed medical decision about sterilization. ${ }^{34}$ This inquiry seeks to protect the autonomy interest of the

31. See Colo. Rev. STAT. § 27-10.5-128(2) (Supp. 1985) ("No person with developmental disabilities who has not given consent shall be sterilized."). In 1981, the Colorado Supreme Court carved out an exception to allow sterilization of mentally retarded minors. See In re A.W., 637 P.2d 366, 375 (Colo. 1981). A California law prohibiting sterilization of all persons under conservatorship, Cal. Prob. CodE $\S 2356$ (1981), was struck down in 1985 in Conservatorship of Valerie N., 40 Cal. 3d 143, 160-61, 707 P.2d 760, 771-72, 219 Cal. Rptr. 387, 398-99 (1985). Several courts have effectively banned sterilization by refusing to allow sterilization in the absence of statutory authority. See infra note 32. Federal law prohibits government funding of the sterilization of minors and incompetents. See Relf v. Weinberger, 372 F. Supp. 1196, 1201 (D.D.C. 1974) (Secretary of HEW has no authority to fund sterilization of minors or mentally incompetent persons who are incompetent to consent to the operation); 42 C.F.R. $\$ 50.207$ (1985) (prohibiting federally assisted familyplanning projects from funding hysterectomies performed solely for the purpose of sterilization).

32. During the 1960's and 1970's, many states repealed eugenic sterilization laws, often without making alternative provisions for sterilization of incompetents. Courts generally rejected petitions to obtain sterilization of mentally retarded persons because of the absence of statutory authority. See Wade v. Bethesda Hosp., 337 F. Supp. 671, $673-74$ (S.D. Ohio 1971); Hudson v. Hudson, 373 So. 2d 310, 312 (Ala. 1979); Guardianship of Kemp, 43 Cal. App. 3d 758, 761-62, 118 Cal. Rptr. 64, 66-67 (1974); A.L. v. G.R.H., 163 Ind. App. 636, 638, 325 N.E.2d 501, 502 (1975), cert. denied, 425 U.S. 936 (1976); Holmes v. Powers, 439 S.W.2d 579, 580 (Ky. Ct. App. 1968); In re M.K.R., 515 S.W.2d 467, 470 (Mo. 1974); Frazier v. Levi, 440 S.W.2d 393, 394 (Tex. Civ. App. 1969). But see In re Sallmaier, 85 Misc. 2d 295, 297-98, 378 N.Y.S.2d 989, 991 (Sup. Ct. 1976); In re Simpson, 180 N.E.2d 206, 208 (Ohio P. Ct. 1962).

In 1978, the United States Supreme Court held that judicial immunity protected an Indiana judge who had authorized the sterilization of a young woman in the absence of statutory authority. Stump v. Sparkman, 435 U.S. 349, 356 (1978). Immunity applied because the judge's decision was not in the "clear absence of all jurisdiction," although the judge may have erred or exceeded his authority. Id. at 356-57.

Although Stump does not directly affirm judicial authority, it opened the path for a series of decisions recognizing the parens patriae power to order the sterilization of mentally disabled persons in the absence of statutory authority.

Several states have enacted statutory provisions that sanction parens patriae sterilization of incompetents. See statutes cited supra note 3. Most recent laws are grounded in the state's parens patriae authority; earlier laws, in contrast, were usually based on the police power.

33. 93 Wash. 2d 228, 608 P.2d 635 (1980).

34. The Hayes court explained that:

[T]he judge must first find by clear, cogent and convincing evidence that the individual is (1) incapable of making his or her own decision about sterilization, and (2) unlikely to develop sufficiently to make an informed judgment about sterilization in the foreseeable future.

Id. at 238,608 P.2d at 641 . 
competent person who has no need for a surrogate decisionmaker. ${ }^{35}$ If the court determines that the person is incompetent, it must then consider specific factors and decide whether sterilization is in the person's best interest. ${ }^{36}$

Most laws following the Hayes decision embody strict procedural and substantive requirements that create a strong presumption against sterilization. These laws presume that there is a conflict of interest between the child and the parent in this context and consequently exclude parents from any role in the decision. ${ }^{37}$ A court makes the sterilization decision in a formal "semi-adversarial" proceeding. ${ }^{38}$ The retarded indi-

35. Some states follow Hayes and require a threshold determination of the person's competency to make the sterilization decision before considering whether nonconsensual sterilization is appropriate. See In re C.D.M., 627 P.2d 607, 612 (Alaska 1981); Wentzel v. Montgomery Gen. Hosp., Inc., 293 Md. 685, 702, 447 A.2d 1244, 1253 (1982), cert. denied, 459 U.S. 1147 (1983); In re Moe, 385 Mass. 555, 566, 432 N.E.2d 712, 721 (1982); In re Grady, 85 N.J. 235, 264, 426 A.2d 467, 483 (1981); In re Terwilliger, 304 Pa. Super. 553, 565, 450 A.2d 1376, 1383 (1982); Colo. Rev. STAT. $\S$ 27-10.5-130 (Supp. 1985); ConN. Gen. Stat. AnN. § 45-788 (West 1981); ME. Rev. Stat. ANN. tit. 34-B, § 7005 (Supp. 1986); OR. Rev. Stat. § 436.225(3) (1985); Utah Code ANN. § 64-10-2 (1986); VT. STAT. ANN. tit. 18, §8707 (Supp. 1986); VA. Code ANN. § 54-325.9 (1982). Although many laws state that the first determination is incompetency, only a few clearly stop the inquiry if competency is found. See ConN. Gen. Stat. AnN. $\$ 45-78 W$ (West 1981); ME. Rev. Stat. ANN. tit. 34-B, $\S 7008$ (1986). A few states permit sterilization on a general finding of incompetency. See In re Penny N., 120 N.H. 269, 271, 414 A.2d 541, 543 (1980) ("The court must [find] that the ward is 'incapacitated' . . . and suffers a 'developmental disability' . . . ."); MinN. STAT. ANN. § 252 A.11-13 (West 1982) (conservatee may be sterilized upon best interest finding).

36. See Hayes, 93 Wash. $2 \mathrm{~d}$ at 237,608 P.2d at 640.

37. The parent's petition generally triggers the appointment of a guardian ad litem to represent the child's interests. See Grady, 85 N.J. at 252, 426 A.2d at 475 (incompetents are best protected by independent judicial decisionmaking, not parents' good faith decision); Hayes, 93 Wash. 2d at 236, 608 P.2d at 640 (parents' interests cannot be presumed to be identical to those of child).

Some laws characterize the court's role as deciding whether to authorize the parent/guardian to consent to sterilization; however, this does not signify any abdication to parental decisionmaking authority in terms of relaxed procedural or substantive standards. See, e.g., Wentzel, $293 \mathrm{Md}$. at 701,447 A.2d at 1254 (guardian's decision authorized only if sterilization is medically necessary).

38. See C.D.M., 627 P.2d at 612 (procedural due process requires full judicial hearing with medical testimony and guardian ad litem to represent incompetent); Grady, 85 N.J. at 252, 426 A.2d at 475 (independent judicial decisionmaking best protects interests of incompetents). Most laws specify a range of procedural protections such as representation by counsel and expert evaluation of the retarded person. See Wentzel, 293 Md. at 703, 447 A.2d at 1253 (independent medical, psychological, and social evaluations by competent professionals); Hayes, 93 Wash. $2 \mathrm{~d}$ at 238,608 P.2d at 641 (comprehensive medical, psychological, and social evaluation); Colo. REv. STAT. § 27-10-5130(1) (Supp. 1985) (appointment of two mental health professionals to perform evaluations); CoNN. GeN. STAT. ANN. § 45-78t (West 1981) (appointment of counsel); IDAho Code $\S 39-3903(a)$,(d) (1985) (appointment of two physicians); ME. Rev. STAT. ANN. tit. 34-B, $\S 7008.2$ (Supp. 1986) (appointment of not less than two disinterested mental health experts); MINN. STAT. ANN. \$252A.13.4 (West 1982) (appointment of counsel and written medical, social, and psychological evaluations); UTAH CODE ANN. § 64-10-8(2) (1986) (appointment of counsel); VT. STAT. ANN. tit. $18, \S 8710$ (Supp. 1986) (appointment of counsel); VA. CODE ANN. $\S 54-325.12 . B$ (1982) (independent medical, social, and psychological evaluations).

Some laws accord other procedural protections such as notice of the proceedings, the right to cross-examine witnesses, and the right to pursue an appeal. See Moe, 385 Mass. at 566-67, 432 
vidual is represented by an attorney, usually a guardian ad litem, who may be directed to oppose the parents' petition for sterilization. ${ }^{39}$ Most of the reform laws allow a court to order sterilization only upon findings based on clear and convincing evidence..$^{40}$

In addition to procedural restrictions, these laws employ rigorous substantive criteria to guide the court's deliberations. Some require inquiries into whether the individual is able to reproduce ${ }^{41}$ and whether she

N.E.2d at 721 (adequate notice, opportunity to be heard, and pursuit of appeal); Grady, 85 N.J. at 264,426 A.2d at 482 (appointment of guardian ad litem and opportunity to present proofs and crossexamine); Terwilliger, $304 \mathrm{~Pa}$. Super. at 565, 450 A.2d at 1383 (same); Colo. Rev. Stat. § 27-10.5129(2), (3) (1982) (notice, presence at proceeding, and opportunity to cross-examine); ConN. GEN. Stat. ANN. $\S \S 45-78$ s to $78 y(a)$ (West Supp. 1986) (notice, opportunity to testify and cross-examine); ME. Rev. Stat. ANN. tit. 34-B, $\S \S 7007.3$, 7008.1 (Supp. 1986) (opportunity to present evidence, call witnesses, and cross-examine); OR. REV. STAT. $\S \S 436.255(2), 436.275(2), 436.315$ (1983) (appointment of counsel on appeal and opportunity to present evidence and cross-examine witnesses); VT. STAT. ANN. tit. 18, $\S \S 8709$ (c), 8711,8714 (Supp. 1986) (notice and right to appeal); VA. CODE ANN. §54-325.11.2 (1982) (notice of proceedings and appointment of counsel).

39. See, e.g., Moe, 385 Mass. at 567, 432 N.E.2d at 721.

40. In In re A.W., 637 P.2d 366, 373-75 (Colo. 1981), the Colorado Supreme Court interpreted Colo. REv. STAT. $\S 15-14-312$ (Supp. 1986) to allow court-ordered sterilization upon a showing of clear and convincing evidence. The law of Maine specifically requires "clear and convincing evidence that sterilization is in the best interest of the person being considered for sterilization." ME. Rev. Stat. AnN. tit. 34-B, § 7013(4) (Supp. 1986). In Wentzel v. Montgomery Gen. Hosp., Inc., 293 Md. 685, 447 A.2d 1244 (1982), cert. denied, 459 U.S. 1147 (1983), the Maryland Supreme Court held that section 13-702 of the Maryland Estates and Trusts Code empowered the court to adopt standards that would ensure the ward's best interest regarding proposed sterilization. The New Hampshire Supreme Court ruled that under a statute mandating court approval of guardianrequested sterilization, N.H. REv. STAT. ANN. § 464-A:25I(c) (1983), the guardian must present clear and convincing proof that the ward is incapacitated, and that the guardian is acting in the best interest of the ward. In re Penny N., 120 N.H. 269, 271-72, 414 A.2d 541, 543 (1980). The proponent of a sterilization in New Jersey must show by clear and convincing evidence that the person to be sterilized lacks the capacity to consent or withhold consent. See Grady, 85 N.J. at 265, 426 A.2d at 483. The Pennsylvania Supreme Court required "proof by clear and convincing evidence that sterilization is in the best interest of the incompetent." Terwilliger, $304 \mathrm{~Pa}$. Super. at 564, 450 A.2d at 1382. Virginia statutory law requires a court to determine "by clear and convincing evidence" that a child is incapable of making a decision before that court can order sterilization. VA. CodE ANN. § 54-325.10 (1982). In order for any incompetent in Virginia to be sterilized, the statutory elements must be shown by clear and convincing evidence. VA. CODE ANN. § 54-325.12 (1982). The Washington Supreme Court stated that the requirements for a court-ordered sterilization must be proven by "clear, cogent and convincing evidence." Hayes, 93 Wash. $2 \mathrm{~d}$ at 238-39, 608 P.2d at 641 .

41. See In re C.D.M., 627 P.2d 607, 613 (Alaska 1981) ("[I]t must then be established that the incompetent is capable of reproduction ...."); Terwilliger, $304 \mathrm{~Pa}$. Super. at 566, 450 A.2d at 1383 ("[T]he person for whom sterilization is requested must be proven capable of reproduction."); Hayes, 93 Wash. 2d at 238, 608 P.2d at 641 ("The judge must find that the individual is . . physically capable of conceiving . . . "); ConN. Gen. STAT. ANN. $§ 45-78 p$ (d) (West Supp. 1986) ("no evidence of infertility"); ME. Rev. Stat. ANN. tit. 34-B, § 7011 (West Supp. 1986) (petition for sterilization must include a "medical statement assessing the physiological capability of the person to procreate"); N.C. GEN. STAT. §635-39 (1984) (petition for involuntary sterilization must state whether patient is likely to procreate).

Some courts seem to presume reproductive capacity from the existence of regular monthly periods and the absence of contrary medical evidence. See Grady. 85 N.J. at 266, 426 A.2d at 483; In re 
is "imminently" likely to engage in sexual activity. ${ }^{42}$ The petitioner will be asked to demonstrate that less drastic forms of contraception have been tried and are not feasible. ${ }^{43}$ The court must also assess the individual's capacity to care for a child. ${ }^{44}$ Some states require a determination that sterilization is medically essential to preserve the life or the physical or mental health of the individual. ${ }^{45}$ In some states, the court must also inquire into the disabled person's understanding of reproductive functions and the relationship between sexual intercourse, pregnancy, and childbirth. ${ }^{46}$ Some laws direct the court to consider the psychological trauma associated with sterilization and alternatively with pregnancy

Truesdell, 63 N.C. App. 258, 283, 304 S.E.2d 793, 808 (1983), aff'd as modified, 313 N.C. 421, 329 S.E.2d 630 (1985). Other courts require further affirmative medical proof. See In re Debra B., 495 A.2d 781, 783 (Me. 1985) (mother's sterilization petition denied because she failed to present clear and convincing evidence to prove that 26 year-old daughter was capable of procreation). Such requirements may involve an intrusive medical examination to prove reproductive capacity (or postponing the sterilization initiative until the person has become pregnant).

42. See Moe, 385 Mass. at 570, 432 N.E.2d at 722; Terwilliger, 304 Pa. Super. at 567, 450 A.2d at 1384; Hayes, 93 Wash. 2d at 238, 608 P.2d at 641; ConN. GEN. STAT. ANN. § 45-78p(d)(4) (West Supp. 1986); UtaH Code ANN. §64-10-8(1)(d) (1983); VT. Stat. ANN. tit. 18, § 8711(c)(3)(B) (Supp. 1986); VA. Code ANN. § 54-325.12.A.1 (1982). But see Grady, 85 N.J. at 266, 426 A.2d at 483 (no need to show likelihood of pregnancy).

43. Many laws require that all less drastic (nonpermanent) contraceptive methods be unworkable and that there be no alternative to sterilization. See C.D.M., 627 P.2d at 613 ; In re A.W., 637 P.2d 366, 376 (Colo. 1981); Moe, 385 Mass. at 569, 432 N.E.2d at 722; Grady, 85 N.J. at 266, 426 A.2d at 483; Hayes, 93 Wash. 2d at 237, 608 P.2d at 640; ConN. Gen. STAT. ANN. § 45-78p(d)(1) (West Supp. 1986); Ga. Code AnN. §31-20-3(c)(2) (1985); Me. Rev. Stat. AnN. tit. 34-B, $\S$ 7013(5)(a) (Supp. 1984); MinN. STAT. § 252A.13.4 (1982); VT. STAT. ANN. tit. 18, $\S 8711$ (a)(3)(E) (Supp. 1986); VA. CodE $\S 54-325.12 . A .2$ (1982); W. VA. CoDE $\S 27-16-1$ (1980).

44. See C.D.M., 627 P.2d at 613; Moe, 385 Mass. at 569, 432 N.E.2d at 722; Grady, 85 N.J. at 266, 426 A.2d at 483; Terwilliger, 304 Pa. Super. at 567, 450 A.2d at 1384; Hayes, 93 Wash. 2d at 238, 608 P.2d at 641; ConN. Gen. Stat. AnN. § 45-78p(d)(6) (West Supp. 1983); Or. Rev. Stat. $\S 436.205(\mathrm{e})$; VT. STAT. ANN. tit. 18, $\S 8711(\mathrm{c})(3)(\mathrm{C})$ (Supp. 1986); VA. Code ANN. § 54325.12.A.4 (1982); W. VA. CoDE § 27-16-1(3) (1980).

45. See A.W., 637 P.2d at 375; Moe, 385 Mass. at 569 n.10, 432 N.E.2d at 722 n.10; ConN. Gen. Stat. AnN. § 45-78p(d)(8) (West Supp. 1983); Me. Rev. Stat. AnN. tit. 34-B, § 7013.5 (Supp. 1984). Colorado requires this finding to protect the individual's health and "fundamental procreative rights." $A . W ., 637$ P.2d at 376. Courts in Maryland must make a finding of medical necessity and also determine whether sterilization is in the individual's best interest. See Wentzel v. Montgomery Gen. Hosp., Inc., 293 Md. 685, 703, 447 A.2d 1244, 1253-54 (1982), cert. denied, 459 U.S. 1147 (1983).

In Conservatorship of Valerie N., 40 Cal. 3d 143, 169, 707 P.2d 760, 777, 219 Cal. Rptr. 387, 404 (1985), the California Supreme Court seemed to require medical necessity because of the absence of a statute. The court directed, pending legislative action, that the procedures for approving intrusive medical procedures for conservatees be applied to sterilization.

In general, the "medical necessity" requirement treats sterilization like other medical procedures for incompetents. However, sterilization is also a reproductive option which normal persons choose for reasons other than health promotion. The New Jersey Supreme Court has rejected a required showing of "medical necessity" as too restrictive of the rights of the retarded person. See Grady. 85 N.J. at $262-63,426$ A.2d at 481.

46. See Grady. 85 N.J. at 266, 426 A.2d at 483 ; Terwilliger, 304 Pa. Super. at 567, 450 A.2d at 1384. 
and childbirth. ${ }^{47}$ Additionally, an inquiry into the individual's preferences about sterilization may be required, although her objection is not determinative. ${ }^{48}$ The Hayes decision and some later laws require findings that medical science is not on the verge of breakthroughs that will correct the individual's disability or make reversible sterilization available. ${ }^{49}$ These various criteria create formidable substantive barriers to the sterilization of mentally retarded persons. ${ }^{50}$

Current law explicitly or implicitly excludes some variables from the court's consideration, such as the state's interest in protecting society from the genetic and financial burden of children produced by retarded persons. ${ }^{51}$ The parents' interest in protecting their child from unwanted

47. See Grady, 85 N.J. at 266, 426 A.2d at 483; Terwilliger, 304 Pa. Super. at 567, 450 A.2d at 1384; Hayes, 93 Wash. 2d at 238-39, 608 P.2d at 641-42; ME. Rev. STAT. ANN. tit. 34-B, § 7013.3.B (Supp. 1986); OR. REV. STAT. § 436.205(1) (1985).

48. Several laws specify that the retarded person has a right to be present at the hearing and further direct the court to inquire about the person's wishes and gain impressions about her competency. See C.D.M., 627 P.2d at $613 \mathrm{n} .17$ (weight given the individual's preferences varies according to ability to comprehend); $A . W$., $637 \mathrm{P} .2 \mathrm{~d}$ at 375 (person's wish not to be sterilized weighs heavily against authorizing the procedure); Wentzel, $293 \mathrm{Md}$. at 703, $447 \mathrm{~A} .2 \mathrm{~d}$ at 1253 (court must allow full opportunity for individual to express views); Grady, 85 N.J. at 265, 426 A.2d at 482 (same); Terwilliger, $304 \mathrm{~Pa}$. Super. at 565-66, $450 \mathrm{~A} .2 \mathrm{~d}$ at 1383 (judge must meet with individual, but not necessarily at hearing); Hayes. 93 Wash. $2 \mathrm{~d}$ at 238, 608 P.2d at 641 (court must elicit individual's views before ordering sterilization); ME. REv. STAT. ANN. tit. 34-B, § 7011.9 (Supp. 1986) (court must consider the person's attitudes or desires regarding sterilization before sanctioning the procedure); UTAH CODE ANN. §64-10-8(3) (1986) (record must include the person's views on issue of sterilization); VA. CODE ANN. § 54-325.11.5 (1982) (court must elicit and thoroughly consider the child's views on sterilization).

49. See Moe, 385 Mass. at 570, 432 N.E.2d at 722; Grady, 85 N.J. at 266, 426 A.2d at 483; Terwilliger, $304 \mathrm{~Pa}$. Super. at 567, 450 A.2d at 1384; IDAHo CODE § 39-3901(e) (1985); UTAH CoDE ANN. §64-10-8(1)(a) (1986); Vt. STAT. ANN. tit. 18, § 8711(c)(3)(D) (Supp. 1986); VA. Code ANN. $\S$ 54-325.11.4 (1982).

50. Indeed, this is the intention. Several courts state clearly that sterilization of an incompetent is seldom in her best interest. For example, the Washington Supreme Court has stated that there is a "heavy presumption against sterilization ... that must be overcome by the person ... requesting sterilization." Hayes, 93 Wash. 2d at 239, 608 P.2d at 641. See also C.D.M., 627 P.2d at 612 (advocates of sterilization bear heavy burden of proving that sterilization is in the incompetent's best interest).

It is interesting to note the similarity between the procedural and substantive requirements of the recent parens patriae laws and the remaining police-power laws. Compare statutes cited supra note 3 with GA. CODE ANN. § 31-20-3(a) (1985); IDAHO CODE § 39-3901(a) (1985); N.C. GEN. STAT. § 35-39(3) (1984).

The police-power laws require these protections because sterilization is viewed as a deprivation of the fundamental right to procreate. It is clear that parens patriae laws are grounded in the same notion. Thus, despite rhetoric about the exercise of reproductive choice, see Grady, 85 N.J. at 247 51,426 A.2d at 473-74, reform laws treat sterilization as an infringement on the person's rights just as do the police-power laws.

51. See Grady, 85 N.J. at 262 n. 8,426 A.2d at 481 n. 8 (court should consider "only the best interests of the incompetent person, not the interests or convenience of society"). Grady rejected the use of sterilization to promote genetic objectives or to prevent the birth of children who would be a burden to society. The Colorado Supreme Court has stated that sterilization is to be allowed only if 
pregnancy or in avoiding the inconvenience associated with menstrual hygiene is also excluded from consideration. ${ }^{52}$ Finally, the disabled individual's interest in promoting family stability by reducing the stress associated with her care may not be considered.

The substantive criteria that guide the decisionmaker are formulated into four kinds of legal rules. The Hayes opinion adopts the most common approach, which could be termed a "mandatory criteria" rule; under this type of rule a court can authorize sterilization only if several specific findings are clearly made. ${ }^{53}$ This rule places a significant burden on the petitioner, limits judicial discretion, and makes it difficult to establish the desirability of sterilization. The "discretionary best interest" standard is a more flexible rule; instead of requiring specific findings, it directs judges to consider and weigh designated criteria in determining whether sterilization is in the incompetent person's best interest. ${ }^{54} \mathrm{~A}$ few

"medically essential" and has emphasized that only the interests of the person herself, and not those of society or her parents, are to be considered. A.W., 637 P.2d at 376. See also Terwilliger, $304 \mathrm{~Pa}$. Super. at 564, 450 A.2d at 1382 ("[A] court should consider only the interests of the individual ....").

52. Some laws require parents to demonstrate their good faith and concern for their child's best interest. See C.D.M., 627 P.2d at 613 (court must examine motivation behind petition); Wentzel, $293 \mathrm{Md}$. at 704-05, 447 A.2d at 1254 ("[T] whe welfare of society or the convenience or peace of mind of the ward's parents or guardian plays no part."); In re Penny N., 120 N.H. 269, 271, 414 A.2d 541, 543 (1980) ("[T]he court must be satisfied that ... the applicants have demonstrated their good faith and that their concern is for the best interests of the ward."); ConN. GEN. STAT. ANN. § 45$78 p(d)(7)$ (West Supp. 1986) (applicants' "primary concern" must be best interest of the incompetent).

53. See Hayes, 93 Wash. $2 \mathrm{~d}$ at $238-39,608$ P.2d at 641 . This kind of law in effect restricts the discretion of the judge; the legislature or appellate court designating the criteria determines the sterilization decision. As a legal decision principle, it may be easier to apply than the discretionary best interest standard, see infra note 54, because it incorporates fewer factual variables. However, the rule as applied may not result in decisions that benefit the individual for whom sterilization is proposed. Thus, costs of error are high. The analysis in Parts II and III of this article suggests that this kind of rule may offer the greatest risk of error. See generally Ehrlich \& Posner, An Economic Analysis of Legal Rulemaking, 3 J. LEGAL STUD. 257, $267-71$ (1974) (discussing correlation of costs to variations in precision of legal rules). For an analysis of variations in types of decision principles in child custody law, see Scott \& Derdeyn, Rethinking Joint Custody, 45 Оніо ST. L.J. 455 (1984).

54. See Penny N., 120 N.H. at 271, 414 A.2d at 543; Terwilliger, 304 Pa. Super. at 564-67, 450 A.2d at 1383-84; Conn. Gen. Stat. AnN. $\S 45-78 y$ (b) (West Supp. 1986); MinN. Stat. $\S 252$ A.13.4 (1982); Or. Rev. STAT. § 436.305(1) (1985); VT. Stat. ANN. tit. 18, § 8712(c) (Supp. 1986).

Even under the discretionary best interest standard, most laws require the court to make a finding of whether the individual is competent to make the sterilization decision. If the individual is incompetent, these laws require the court to consider several substantive criteria and decide whether there is clear and convincing evidence that sterilization is in the person's best interest. Error under this standard may occur if the court fails accurately to weigh the various criteria in the decision. Maryland requires a finding of medical necessity but also directs the court to weigh several factors in determining whether sterilization is in the person's best interest. Wentzel. $293 \mathrm{Md}$. at 702-03. 447 A.2d at 1253-54. Thus, a finding that sterilization is in the person's best interest would not suffice; sterilization must also be a medical necessity. The requirement of a best-interest finding seems su- 
states have adopted the "substituted judgment" approach first proposed by the New Jersey Supreme Court in In re Grady. ${ }^{55}$ Grady directs the court to consider the Hayes criteria and any other relevant factors in order to make the decision that the disabled person would make for herself if she were competent. ${ }^{56}$ Finally, a few jurisdictions simply prohibit the sterilization of anyone found by the court to be incompetent to give informed consent to the medical procedure. ${ }^{57}$

On a functional level, the various legal rules seem to promote different objectives. A rule prohibiting sterilization without the subject's informed consent apparently aims to protect only the right to procreate. Sterilization is by definition a violation of this right, regardless of the person's preferences. At the other extreme, the substituted judgment standard attempts, at least in theory, to approximate the choice that the

perfluous, since a procedure that is medically necessary would arguably always be in the person's bes: interest.

55. 85 N.J. 235, 426 A.2d 467 (1981).

56. Id. at 264-67, 426 A.2d at 482-83. See also In re Moe, 385 Mass. 555, 565-71, 432 N.E.2d 712, 720-23 (1982); UTAH CODE ANN. § 64-10-8(4) (1986). The substituted judgment doctrine has frequently been used in cases involving medical decisions for individuals who have become incompetent. Many of these decisions involve attempts to withdraw life-sustaining treatment from terminally ill patients. The landmark case is In re Quinlan, 70 N.J. 10, 355 A.2d 647, cert. denied, 429 U.S. 922 (1976). The New Jersey Supreme Court held that a 21 year-old woman in a persistent vegetative state had a right, which her father as her appointed guardian could exercise on her behalf, to withdrawal of life-sustaining treatment. Id. at $41-42,355$ A.2d at 664 . The objective of the substituted judgment approach is for the decisionmaker to "step into the shoes" of the incompetent in order to make a decision that subjectively reflects what the individual's values and preferences would be were she competent. Id. In theory, the decision may reflect subjective idiosyncratic values and need not be the one that objectively reflects the person's best interest.

Courts have applied the substituted judgment approach in cases involving individuals who have never been competent. See Superintendent of Belchertown State School v. Saikewicz, 373 Mass. 728 , 750-51, 370 N.E.2d 417, 430 (1977) (chemotherapy withheld from profoundly retarded 67 year-old man). The application of the substituted judgment approach is problematic because it requires the surrogate decisionmaker to discern the competent values and preferences of a never-competent person.

By establishing objective criteria to aid in approximating the disabled person's best interest, the cases applying the substituted judgment approach implicitly recognize the pitfalls of a subjective inquiry. See Grady, 85 N.J. at 266-67, 426 A.2d at 483 (determination based on a range of factors, including incompetency). In this way, despite the rhetoric, the substituted judgment approach is similar to the discretionary best interest approach. The Wisconsin Supreme Court accurately characterized the effort to reach the sterilization decision that the incompetent retarded person would make taking into account anything that would have been relevant to her including her incompetency as "legal legerdemain." In re Guardianship of Eberhardy, 102 Wis. 2d 539, 566, 307 N.W.2d 881, 893 (1981).

A presidential commission recommended that courts apply an objective best interest standard to surrogates' decisions to withdraw life-sustaining treatment from persons who had never been competent, although the commission endorsed the substituted judgment approach for persons who had once expressed competent preferences. President's Comm'N FOR the Study OF Ethical. Problems in Medicine and Biomedical. and Behavioral. Resfarch, Substantive and Procedural. Principles of Decisionmaking for Incapacitated Patients 179-88 (1983).

57. See supra note 31 . 
individual would make if she were competent. Between these two extremes are laws that attempt to protect the individual's interest in procreation from parental or state interference. ${ }^{58}$ Despite variation, however, the reform laws are all based on a paternalism model. The model protects the mentally disabled person by establishing a heavy presumption against sterilization and by requiring a judicial decisionmaker.

\section{The Limits of Good Intentions: Some Problems with the Paternalism Model.}

The rigorously protective approach of the paternalism model may seem to offer a desirable level of protection when parents propose sterilization. The irreversibility of the medical procedure in itself justifies caution. Given the abuses of the past and lingering biases toward mentally retarded persons, a rule that constrains the surrogate decisionmaker by a strong presumption against sterilization would seem to be justified.

Some retarded persons, however, may be hurt by laws based on the paternalism model because that model places the interest in procreation above all other interests, including the interest in avoiding pregnancy. Like other people, a retarded person may have an interest in engaging in a sexual relationship without fear of pregnancy. This objective could often be most satisfactorily implemented through sterilization, but that option usually will be unavailable under current law. Current law also unnecessarily restricts the individual's interest in reproductive autonomy. Although accorded rhetorical deference, this interest is protected only if the individual is found to be intellectually capable of making the medical decision. If the person is found to be incompetent, a court decides whether sterilization is in her best interest. Yet it seems possible that some persons who may be incapable of informed medical decisions may be capable of meaningful reproductive choices (to produce a child or avoid pregnancy). The basis of the restricted conception of individual autonomy under the paternalism model is unclear. It may derive from a desire to protect vulnerable individuals from those who threaten their right to procreate. Alternatively, it may be based on a simplistic analysis of the mentally disabled person's interest in reproductive autonomy.

58. The case law and commentary discuss two seemingly contradictory objectives of sterilization law. On the one hand, sterilization is authorized as a means of facilitating reproductive choice. On the other hand, sterilization is characterized as a deprivation of a fundamental right. See supra note 20. This characterization is the basis of the general requirement that the criteria supporting sterilization be established by clear and convincing evidence. Courts cite Addington v. Texas, 441 U.S. 418 (1979), which required a clear and convincing standard in civil commitment proceedings because a deprivation of liberty was involved. This analogy suggests that sterilization is viewed by some courts as deprivation of procreative capacity rather than a widely used contraceptive option that could be made available through a surrogate. 
Another problematic aspect of this model is the presumed conflict of interest in all cases between parent and child. Because every disabled person is assumed to have an interest in procreation that conflicts with her parents' effort to obtain sterilization, parental or family interests are excluded from the decision calculus. This approach may protect the mildly disabled person who may have an interest in making her own choices about reproduction. But it could be harmful for the more severely retarded person. Parents who care for a severely disabled child assume a substantial burden. It is not clear that the law serves the interest of such a person by augmenting that burden, especially if the presumed interest in procreation in fact does not exist. It is also not clear that a surrogate will be a better decisionmaker than the parents, who presumably know and love the child.

It is unlikely that sterilization, the contraceptive choice of many normal persons, is only infrequently desirable for retarded persons. Yet sterilization will rarely be ordered in many states because most parents will be unable to meet the rigid criteria set out in the sterilization laws. ${ }^{59}$ These laws erect obstacles to sterilization in order to protect a possible interest in procreation, ${ }^{60}$ yet they do not grapple directly with the basic question: How can it be determined whether a given individual has this interest? In the absence of such an inquiry, it is unclear whether the purported safeguards serve an actual protective function or whether they simply burden the petitioning parent and ultimately the affected individual. ${ }^{61}$

\section{The Interests of the Retarded Person in Sterilization: AN AUTONOMY MODEL}

This Part develops an alternative approach to sterilization of retarded persons, premised on the primacy of individual and family autonomy. First it explores the interest in reproductive autonomy and the extent to which mental retardation affects the ability to make a meaningful decision to have children or to avoid pregnancy. It then examines the residual interests that may be important for the severely disabled person

59. See supra notes $37-50$ and accompanying text.

60. See supra note 58 .

61. By way of example, consider the blanket requirement that temporary alternatives be tried and found unworkable. This requirement assumes that the person may have an interest in having children in the future (and that a nonpermanent form of contraception is therefore desirable) without inquiry into whether or not she actually does. A more extreme example is the rule that authorizes sterilization only if it is a medical necessity. Such a requirement virtually forecloses sterilization for contraceptive purposes. It presumes that sterilization benefits the individual only if mandated by critical health needs; otherwise, preserving reproductive capacity is presumed to be of primary importance. 
who is incapable of autonomous reproductive choice-interests involving medical risks and benefits, human dignity, and stable family life.

\section{A. Reproductive Autonomy and the Impact of Mental Disability.}

Analysis of reproductive autonomy ${ }^{62}$ focuses on the individual's substantive interest in producing children or avoiding pregnancy as well as on her interest in controlling the decision. It might seem artificial to examine each interest separately and to distinguish the mentally retarded person's interest in making her own decisions from the underlying substantive choices themselves. A retarded person's disability, however, can differentially affect her interest in alternative outcomes because the decision to procreate and the decision not to procreate each require different intellectual capabilities. Furthermore, a person who is unable to make an autonomous choice about reproduction might nonetheless have an interest in the substance of the decision made by others for her. ${ }^{63}$ Thus, a separate analysis of each dimension of the reproductive autonomy interest is indicated.

\section{The Interest in Preventing Reproduction. The Supreme Court} decisions that recognize a woman's right to make contraception and abortion decisions ${ }^{64}$ are based on a right not to procreate. ${ }^{65}$ Married individuals have a legally sanctioned right to cohabit without producing unwanted children. ${ }^{66}$ Unmarried persons and minors may not have the right to engage in sexual activity, but they do have the right to avoid the

62. See infra note 92 . Reproductive autonomy is the constitutionally protected interest individuals have in private autonomous decisions about whether or not to have a child. See Roe v. Wade, 410 U.S. 113, 153 (1973) (fundamental right to choose abortion); Griswold v. Connecticut, 381 U.S. 479, 484-86 (1965) (fundamental right of marital privacy located in "penumbras" of first, third, fourth, and ninth amendments). Reproductive privacy is an important aspect of a more general constitutional right of privacy that extends to decisions about marriage and childrearing, and more broadly to protection of bodily integrity and avoidance of personal disclosures. In Whalen v. Roe, 429 U.S. 589 (1977), the Supreme Court described the right of privacy as encompassing both an "interest in avoiding disclosure of personal matters" and a distinct interest in "independence in making certain kinds of important decisions." Id. at 599-60. See generally L. TribE, American Constitutional LAw 921-34 (1978) (tracing development of right to privacy in reproduction decisions).

63. This is also true of many decisions made for children. Children have an interest in the substantive decisions their parents or the state make concerning their health and safety, even though they are disabled from making autonomous choices themselves and thus have no recognized autonomy interest.

64. See supra note 19.

65. Although the Court has characterized the right of reproductive privacy as the right to decide whether or not to bear a child, see Eisenstadt v. Baird, 405 U.S. 438, 453 (1972), Professor Robertson correctly points out that the interest at stake in abortion and contraceptive cases is the interest in avoiding conception and childbirth. See Robertson, supra note 23, at 405-06.

66. See Griswold v. Connecticut, 381 U.S. 479, 481-86 (1965). 
potential costs of sexual intercourse. ${ }^{67}$

These costs are varied and substantial. If a woman does not want to become pregnant or give birth, the pain, discomfort, medical risk, and lasting physical and emotional effects of the experience are substantial burdens. For an unmarried female, pregnancy can be an embarrassing social disability. Responsibility for an unwanted child can entail substantial financial costs and may limit the social, career, and educational opportunities available to the parent.

The mentally retarded person may have an interest in avoiding pregnancy that is comparable to that of the normal person. She might want to avoid the costs of sexual freedom-the physical burden of pregnancy and the discomfort of childbirth. She might also derive a benefit from avoiding the psychological burden caused by the birth of a child who is unwanted or for whom she cannot care. The stress of parental responsibility and the negative effect on social, educational, and employment opportunities are costs that are as onerous for the retarded individual as for others.

2. The Interest in Procreation. In defining the constitutional doctrine of reproductive privacy, the Supreme Court has seldom focused directly on the right to procreate. ${ }^{68}$ Nonetheless, the importance and constitutionally protected status of this right are clear. The Court has described procreation as a "basic civil right of man." 69 The right is protected by the constitutional tradition of family privacy and supported by a strong historical tradition. ${ }^{70}$ Despite recent concerns about population

67. The Supreme Court has never struck down a state statute proscribing sexual activity between unmarried persons. However, the Court did strike down a Massachusetts law that limited access to contraceptives. See Eisenstadt, 405 U.S. at 454-55. In Carey v. Population Servs. Int'l, 431 U.S. 678 (1977), the Court held that a New York law restricting sale of nonprescription contraceptives to minors was unconstitutional. The Court noted, however, that the Constitution "does not bar state regulation of the sexual behavior of minors." Id. at 694 n.17. The Court stated in Eisenstadt that it would be unreasonable to believe that the legislature intended to "prescribe pregnancy as punishment for fornication." Eisenstadt, 405 U.S. at 448 . The Court has recently recognized that protection of sexual privacy outside of marriage may be restricted in nature. In Bowers v. Hardwick, 106 S. Ct. 2841 (1986), it rejected the challenge of an adult homosexual arrested under a Georgia antisodomy law for engaging in consensual sexual activity in his home. Id. at 2843 . Because the opinion emphasized the homosexual nature of the activity, its broader application is unclear.

68. Professor Robertson points out that this right has seldom been subject to state regulation; for this reason, perhaps, it has seldom been examined and is "ill-defined." See Robertson, supra note 23 , at 406 .

69. Skinner v. Oklahoma ex rel. Williamson, 316 U.S. 535, 541 (1942). Skinner struck down, on equal protection grounds, an Oklahoma law that authorized sterilization of some but not all habitual criminals.

70. Because of our strong tradition of family privacy, many would reject the notion of state interference in a couple's freedom to have a child. Other countries have overtly discouraged procre- 
control, the right to procreate remains relatively unambiguous ${ }^{71}$-in contrast to the right not to procreate, which in the abortion context is limited by the interest of the fetus. Indeed, direct restrictions on reproduction have been tolerated only when applied to mentally disabled persons through involuntary sterilization laws.

Procreation as a "basic civil right" is closely linked to the doctrine of family privacy and the right of parents to rear their children. In Stanley v. Illinois, ${ }^{72}$ the Supreme Court held that an unmarried natural father who was rearing his children had a constitutionally protected parental interest. The Court implicitly linked this parental interest to procreative rights, stating that "[t]he Court has frequently emphasized the importance of the family. The rights to conceive and raise one's children have been deemed 'essential." "73 Earlier, in Meyer v. Nebraska, ${ }^{74}$ the Court defined the rights "to marry, establish a home and bring up children"75 as liberties protected by the fourteenth amendment. In contrast, the parental interest of one who has reproduced without assuming parental responsibilities is given minimal legal and constitutional recognition. In Lehr v. Robertson, ${ }^{76}$ the Court held that a natural father who had as-

ation in pursuit of policies of population control. The Chinese government offers "one-child" awards that are available upon sterilization or a promise not to have additional children. These awards take the form of cash payments and the payment of the child's medical, educational, and nursery expenses. These "one-child" awards also may take the form of time off from work and increased pensions. The Chinese government imposes penalties upon parents who have more than one child and these penalties become more severe as more children are born. See Goodstadt, China's One-Child Family, 8 Population \& Dev. Rev. 37, 48 (1982).

71. The reduction in the size of the American family in recent years may be attributed to economics and better contraception but not to coercive governmental policies. See Mintz \& Kellogg, Recent Trends in American Family History, 81 Hous. L. Rev. 789 (1984).

72. 405 U.S. 645 (1972). In Stanley, the Court struck down an Illinois statute that allowed removal, without a hearing, of the children of an unmarried father from the father's custody upon the mother's death. Id. at 658. The Court affirmed the father's interest in the "children he has sired and raised." Id. at 651 .

73. Id. (emphasis added).

74. 262 U.S. 390 (1923). Meyer was the first decision to suggest a constitutionally protected interest in family privacy. The Court struck down a Nebraska law restricting the use of foreign languages in schools; part of the Court's rationale was that the law restricted parental authority. Id. at 400 .

75. Id. at 399 .

76. 463 U.S. 248, 263-64 (1983). Lehr is consistent with the legal trend that began with Stanley. In general, the courts have held that an unmarried father's relationship with his child is to be accorded substantial legal protection if the father has assumed parental responsibility. The Supreme Court did state in Lehr, however, that the "mere existence of a biological link does not merit equivalent constitutional protection." Lehr, 463 U.S. at 261. The Lehr Court characterized the natural father's genetic link as an "opportunity" to assume a unique relationship with the child. If he fails to do so, he loses his parental rights. Id. at 262.

Because a natural mother undergoes pregnancy and gives birth, she may be accorded a superior legal status over a natural father. See Lehr, 463 U.S. at 260 n.16. Nonetheless, she may lose this 
sumed no responsibility for his child was not entitled to notice of the child's adoption by the mother's husband.

The right to procreate is the right to produce one's own children to rear. The right presumes and indeed requires an intention as well as an ability to assume the role of parent. Without this purpose and capacity, the "right" is limited to a right to conceive, carry, and bear a child. ${ }^{77}$ To be sure, these components of the reproductive process may have independent value to the individual. For example, a man might wish to donate sperm to perpetuate his lineage even though the children conceived will remain unknown to him. A woman might want to act as a surrogate mother because she finds pregnancy and childbirth to be meaningful and satisfying experiences. But neither of these desires, legitimate though they may be, implicates a fundamental right. Indeed, debate concerning the constitutional implications focuses on the reproductive rights of the prospective rearing parents. ${ }^{78}$ It is the objective of rearing the child - of establishing a family - that elevates the right to procreate to a lofty status.

status if she fails to care for the child. See infra notes 80-81; see also Caban v. Mohammed, 441 U.S. 380 (1979); Quilloin v. Walcott, 434 U.S. 246 (1978).

77. Professor Robertson describes three aspects of the right to procreate: conception, gestation and birth, and childrearing. Robertson, supra note 23, at 408-10. In contrast to the view expressed in this article, Professor Robertson values each aspect of the right to procreate independently and suggests that the benefit derived from conception or gestation should not be sacrificed because the person lacks the ability to raise a child. Id. at 413 .

78. Surrogate mother contracts, in particular, have been controversial. See Robertson, Surrogate Mothers: Not So Novel After All, HASTINGS CENTER REP., Oct. 1983, at 28; Wadlington, Artifcial Conception: The Challenge for Family Law, 69 VA. L. REv. 465, 479-82 (1983). Some courts have rejected surrogate mother contracts as contrary to public policy "because they involve an exchange of money for the baby." Doe v. Kelley, 106 Mich. App. 169, 173-74, 307 N.W.2d 438, 441 (1981), cert. denied, 459 U.S. 1183 (1983). The cases focus on the contracting couple's argument that the contract should be upheld to protect their constitutional right of reproductive privacy. See, e.g., Surrogate Parenting Assocs. v. Commonwealth ex rel. Armstrong, 704 S.W.2d 209, 212 (Ky. 1986) ("The decision whether or not to beget or bear a child is at the very heart ... of constitutionally protected choices."). Professor Robertson argues that infertile couples have a right to participate in noncoital cohabitative arrangements such as surrogate contracts. Robertson, supra note 23, at 428. The infertile couple may have no other means to exercise a decision to have a child except through some noncoital arrangement. This argument is only compelling, however, if the couple desires a child to rear. No one argues that the surrogate mother is exercising her right to procreate by becoming pregnant through a surrogate arrangement.

Artificial insemination by a donor (AID) is characterized not as an exercise of the donor's reproductive rights, but as a means of providing the mother with a child. See Surrogate Parenting Assocs., 704 S.W.2d at 211-12. This characterization is appropriate because the donor has no intention of assuming parental responsibilities. Many states have passed laws protecting the donor from fatherly responsibilities not contemplated at the time of the contract. The Uniform Parentage Act provides that the husband of the woman inseminated with the donor's sperm is the natural/legal father. See U.P.A. $\S 5$ (1986); see also CAI.. Civ. ConE $\S 7005$ (West 1983); Мich. СомP. LAws ANN. $\$ 700.111$ (2) (West 1980). Indeed, the sperm donor's status as natural father only becomes legally relevant in the rare instance when he seeks to assume parental responsibilities. Sec. e.g.. C.M. v. C.C., 152 N.J. Super. 160, 167-68, 377 A.2d 821, 824-25 (1977). 
Traditional family law also implicitly supports this analysis of the limited nature of the right to procreate. The law favors biological parents over mere caretakers, recognizing the interest that natural parents have in pregnancy, childbirth, and the genetic link to future generations. ${ }^{79}$ However, biological parents who cannot or will not fulfill their responsibilities as parents lose the legal protection created by their status. For example, abandonment of a child is grounds for termination of parental rights in every state. ${ }^{80}$ Similarly, parental neglect or abuse that is not remediable and that results in intolerably poor child care will also result in state intervention to remove the child and limit or extinguish the natural parent's legal interest in the child. ${ }^{81}$

Historically, it was commonly believed that mentally retarded persons were per se unable to fulfill their responsibilities as parents. Even today, many child protection statutes list mental retardation as a factor supporting a finding of unfitness. ${ }^{82}$ This presumption of incompetency

79. There has traditionally been a legal presumption favoring natural parents in custody disputes with third parties, even if the nonparent has been the child's primary caretaker. See SpenceChapin Adoption Serv. v. Polk, 29 N.Y.2d 196, 201, 274 N.E.2d 431, 434, 324 N.Y.S.2d 937, 941-42 (1971). Only if the natural parent is unfit will custody go to a nonparent over a parent. See Bennett v. Jeffreys, 40 N.Y.2d 543, 545-46, 356 N.E.2d 277, 280-81, 387 N.Y.S.2d 821, 823-24 (1976). The Kansas Supreme Court struck down a statutory provision favoring the child's "psychological parent" as a violation of the natural parents' fundamental right to custody. Sheppard v. Sheppard, 230 Kan. 146, 153-55, 630 P.2d 1121, 1127-28 (1981), cert. denied, 455 U.S. 919 (1982). Many statutes, however, give the state very broad authority to intervene in families and remove children for abuse and neglect. See, e.g., Cal. Welf. \& INST. CodE $§ 300$ (West Supp. 1986).

80. Abandonment statutes generally specify a period of time after which the state may terminate the parent's rights. See, e.g., Miss. CoDE ANN. § 93-15-103(3)(a) (Supp. 1985) (six months if child is under age three; one year if child is over age three); MonT. CoDE ANN. $\S \S 41-3-102(3)$ (d), 41-3-609(1)(b) (1985) (six months); UTAH CoDE ANN. § 78-3a-48(1)(b) (Supp. 1986) (six months); VA. CODE ANN. § 16.1-283(D) (Supp. 1986) (six months).

81. The state may terminate parental rights if the parents are unable or unwilling to remedy the conditions or behavior that led to the child's removal. Unless the parents' behavior presents a serious threat to the child, or is clearly not remediable, most states require that before termination can be ordered, services be provided to assist in remediation and the parent be given an opportunity to rectify the conditions that led to removal. See, e.g., Mont. CodE ANN. § 41-3-609(1)(c)(i), (ii) (1985); VA. Code ANN. $\S 16.1-283(C)(2)(b)$ (Supp. 1986); Wash. Rev. Code ANN. $\S 13.34 .130$ (2)(a) (Supp. 1986). Many states require that the social service agency submit a fostercare plan providing for remedial services to facilitate the child's return. See, e.g., VA. CodE ANN. $\S 16.1-281$ (Supp. 1986); WASH. REv. CodE ANN. § 13.34.130(2) (Supp. 1986).

If, after a reasonable period of time, parents have not demonstrated progress such as would make the child's return feasible, the state may hold a hearing to terminate the parents' rights and free the child for adoption. See, e.g., VA. CoDE ANN. $\S \S 16.1-283(A),(C)(2)$ (Supp. 1986). The Supreme Court has acknowledged the seriousness of this deprivation by requiring a clear and convincing standard of proof. See Santosky v. Kramer, 455 U.S. 745, 747-48 (1982).

82. See Kan. Stat. AnN. §38-1583(b)(1) (Supp. 1985); Miss. Codf: AnN. §93-15103(3)(d)(i) (Supp. 1985); Mo. ANN. STAT. § 211.447.2(2)(a) (Vernon Supp. 1986); S.C. Coil: ANN. $\S 20-7-1572(6)$ (Law. Co-op. 1976); VA. CoDI: ANN. §16.1-283(B)(2) (Supp. 1986).

Courts have frequently based withdrawal of custody or termination of parental rights on parents' mental retardation. See In re Jeannie Q., 32 Cal. App. 3d 288, 298-302. 107 Cal. Rptr. 646. 
has been challenged by growing evidence that some mildly retarded individuals may be able to function as adequate parents. ${ }^{83}$ Under my analysis, these individuals may have a protected interest in procreation.

The retarded person's interest in having children is more closely linked to her intellectual and functional ability than is her interest in avoiding pregnancy. A severely disabled person may have no affirmative interest at all in producing offspring, if conception, gestation, birth, and childrearing have no meaning to her. A less-impaired person may enjoy pregnancy or express a childlike interest in the notion of having her own child, but may be unable to care for a child due to her disability. ${ }^{84} \mathrm{~A}$ mildly retarded person may have an interest in reproduction that approximates that of the normal individual; she may desire children of her own and may be capable of caring for them. ${ }^{85}$ This article takes the position that the individual who is capable of caring for a child has a legally protectable interest in procreation, and that the individual who lacks this capability does not. ${ }^{86}$

653-57 (1973) (state withdrawal of retarded mother's custody of five children upheld because mother's IQ was 61 and two children showed evidence of malnutrition); In re Devine, 81 Ill. App. 3d 314, 319-20, 401 N.E.2d 616, 620-21 (1980) (termination of parental rights upheld where father's IQ was 63, mother's IQ was 55, and children had been neglected); In re McDonald, 201 N.W.2d 447, 449-53 (Iowa 1972) (termination of parental rights upheld where father's IQ was 74, mother's IQ was 47 , and mother was unable to cope with typical child-care problems); State v. C.N.S., 319 S.E.2d $775,780-82$ (W. Va. 1984) (termination of mentally retarded parents' rights upheld without probationary period because there was no reasonable likelihood of improvement); In re C.M., 556 P.2d 514, 519 (Wyo. 1976) (termination of parental rights upheld since retarded parents would require full-time assistance).

83. See supra note 30. Several commentators have challenged the notion that mental retardation creates a presumption of parental unfitness. See Shaman, supra note 30, at 72-73; Wald, supra note 28, at 14-15; Note, The Law and the Problem Parent: Custody and Parental Rights of Homosexual, Mentally Retarded and Incarcerated Parents, 16 J. FAM. L. 797 (1978); Note, Low Intelligence of the Parent: A New Ground for State Interference with the Parent-Child Relationship?, 13 J. FaM. L. 379 (1974).

Some courts in recent years have viewed the capabilities of mentally retarded parents in more positive light. See, e.g., In re Montgomery, 62 N.C. App. 343, 303 S.E.2d 324 (1983) (order terminating parental rights of mentally retarded parents overturned; although parents could not provide some economic needs, they were providing for daily care and were able to summon help in emergency situations), rev'd, 311 N.C. 101, 111, 316 S.E.2d 246, 253 (1984); see also In re L. Children, 131 Misc. 2d 81, 499 N.Y.S.2d 587 (N.Y. Fam. Ct. 1986) (child-care agency's petition to terminate mother's parental rights dismissed because agency had not made diligent efforts to encourage and stengthen parental relationship and evidence failed to establish that mental retardation would preclude mother from caring for child).

84. For example, W., an individual evaluated at the Forensic Psychiatry Clinic at the University of Virginia, was a severely retarded 15 year-old girl whose mother had recently had a baby. W. treated her brother like a doll and required constant supervision when she played with him. After her brother was born, she frequently expressed a wish for her own baby.

85. See supra notes $29-30$ and accompanying text.

86. Onora O'Neill argues that the right to procreate should be contingent on a willingness and ability to rear or to delegate childcare responsibilities. See O'Neill, Begetting. Bearing and Rearing. in HAving ChII.DRIin 26 (O. O'Neill \& W. Ruddick eds. 1979). I would argue that the parent who 
Under this analysis, severely retarded individuals who are not capable of fulfilling the basic responsibilities of parenthood do not have a legally protectable interest in procreation. The meaning of procreation for such a person is limited to the satisfaction she might derive from conception, pregnancy, and birth and from producing a child who will be cared for by others. The absence of a legally protectable interest in procreation does not, however, mean that nonconsensual sterilization is always appropriate for such a person. It does suggest that the decisionmaker should not exaggerate the retarded person's interest in procreation when determining whether sterilization is appropriate.

The analysis proposed here, which focuses on the retarded person's ability to fulfill the basic responsibilities of parenthood rather than on some absolute right to procreate, is consistent with current legal policy regarding contraception and abortion for retarded persons. Despite strong pronouncements in the sterilization context about the mentally disabled person's "right to procreate," it is clear that most states permit restrictions on the exercise of this right by retarded individuals who are unable to function as parents. Little controversy arises when a parent seeks to prevent a mentally disabled child from becoming pregnant. ${ }^{87}$ Even in those states where sterilization is barred, parents and guardians can consent to contraception and even abortion for incompetent persons. ${ }^{88}$ These laws acknowledge that the incompetent person's interest in

delegates some responsibility due to a physical disability (for example, a quadraplegic parent) may have an interest in reproduction and parenting if she is still able to guide the child's upbringing. However, the person who cannot fulfill any important dimension of the parental role has at most an ephemeral interest in reproduction-one that does not merit legal recognition.

87. It is arguable that parents may not responsibly ignore a legitimate risk that their mentally disabled child may become pregnant. Cf. Foy v. Greenblott, 141 Cal. App. 3d 1, 8-14, 190 Cal. Rptr. 84, 89-93 (1983) (institutionalized individual who became pregnant unsuccessfully sued facility responsible for her care for failure to provide contraception). Normalization policies assume mentally retarded persons will use contraceptives when engaging in sexual activity.

88. The California Supreme Court declared unconstitutional a law that prohibited sterilization of a conservatee with the conservator's consent, but that permitted the conservator to consent to contraception and abortion. See Conservatorship of Valerie N., 40 Cal. 3d 143, 707 P.2d 760, 219 Cal. Rptr. 387 (1985). The court stated:

At present her conservators may, on Valerie's behalf, elect that she not bear or rear children. As means of avoiding the severe psychological harm which assertedly would result from pregnancy, they may choose abortion should she become pregnant; they may arrange for any child Valerie might bear to be removed from her custody; and they may impose on her other methods of contraception, including isolation from members of the opposite sex. They are precluded from making, and Valerie from obtaining the advantage of, the one choice that may be best for her, and which is available to all women competent to choosecontraception through sterilization.

Id. at 161, 707 P.2d at 771, 219 Cal. Rptr. at 398-99. Parents and guardians of mentally retarded persons are generally authorized to consent to contraceptive and other medical treatment subject to specific exclusions such as sterilization, psychosurgery, or electroshock treatment. See MonT. COD): ANN. \$ 72-5-321(2)(c) (1985); OHIO RI:V. Col)1: ANN. \$ 5122.271(c) (Anderson Supp. 1985); UT NH COII: ANN. \$75-5-312(1)(c) (1978). 
avoiding pregnancy is more important than a theoretical interest in reproduction. Only sterilization law, responding to its unsavory history, seems to support an unqualified interest in procreation without regard to the person's capacity to fulfill the responsibilities of parenthood.

Defining the level of incompetency in parenting skills that signals the absence of a protectable interest in procreation will undoubtedly be a difficult and inexact process. ${ }^{89}$ An erroneous decision to sterilize is probably more costly than an erroneous decision not to sterilize. ${ }^{90}$ Therefore, the risk of error should be tipped in the direction of optimism about the individual's potential parenting capacity. But if the retarded person is so severely and irremediably impaired that she could never provide a child with minimally adequate care, ${ }^{91}$ and if the state would therefore be justified in terminating her parental rights were she ever to have a child, then she has no protectable interest in procreation.

\section{Personal Autonomy and the Right to Make Reproductive} Choices. The importance of the principle of personal autonomy in defining the relationship between the individual and the state is well established in our constitutional and legal tradition. ${ }^{92}$ Legal protection of the freedom of the individual to make personal choices about religious practice, expression of opinion, place of residence, and employment is grounded in the value of personal autonomy. Few decisions are more important to the individual than the decision whether or not to have children. Thus, inherent in the substantive interests in producing and rearing one's own children and, alternatively, in avoiding the burdens of reproduction is the individual's interest in exercising control over repro-

89. See infra notes $142-43$ and accompanying text.

90. Sterilization by vasectomy or salpingectomy may be reversible, although this factor should not enter the decisionmaking process because it is not predictable.

91. It is the irremediable quality of the impairment that distinguishes the retarded person from others who have failed at parenting. The fact that the normal parent has repeatedly had children removed from her custody may be persuasive evidence of an inability to provide minimally adequate care. Her inadequacy as a parent, however, is not necessarily irremediable; her theoretical future interest in procreation and in bodily integrity would make involuntary sterilization unacceptable.

92. John Stuart Mill's On Liberty is the classic political philosophy treatise on autonomy. State control over individual action is legitimate, in Mill's view, only if necessary to prevent harm to others. J. MiLL, ON LiBERTY $77-79$ (1859). In American constitutional law, the principle of autonomy is the basis of many of the protections in the Bill of Rights. It inheres in the broader right of privacy which includes both notions of autonomy and freedom from disclosure of personal facts. See Whalen v. Roe, 429 U.S. 589, 598-600 (1977). Justice Stevens has described the individual's "interest in independence in making certain kinds of important decisions" as central to the right of privacy. Id. at 599-600. For an examination of the evolution and contours of the broader constitutional rights of privacy and personhood, see L. TRIBE, supra note 62, at 886-990. See also Note, $A$ Taxonomy of Privacy: Repose, Sanctuary, and Intimate Decision, 64 CALIF. L. Rev. 1447 (1976). 
ductive decisions. ${ }^{93}$

The Supreme Court's opinions on abortion and contraception emphasize the constitutional status of the right to make reproductive decisions free from state interference. ${ }^{94}$ The Court has recognized that this interest is held by competent adults ${ }^{95}$ as well as minors who are capable of making their own decisions. ${ }^{96}$ Neither the parents of a mature minor nor a husband may veto a woman's right to make an autonomous choice to obtain an abortion or continue the pregnancy. ${ }^{97}$

Until recently, mental disability was the basis for a blanket presumption of incompetency. Even libertarians such as John Stuart Mill assumed that retarded persons as a class (like children) were not to be regarded as autonomous persons. ${ }^{98}$ In contrast, modern commentators

93. The Supreme Court has stated that "[i]f the right of privacy means anything, it is the right of the individual, married or single, to be free from unwarranted governmental intrusion into matters so fundamentally affecting a person as the decision whether to bear or beget a child." Eisenstadt v. Baird, 405 U.S. 438, 453 (1972).

94. See id.; Carey v. Population Servs. Int'l, 431 U.S. 678, 684-85 (1977).

95. The Supreme Court focused on protection of marital privacy in striking down Connecticut's ban on contraceptive use in Griswold v. Connecticut, 381 U.S. 479, 485-86 (1965). The Court later held that the right extended to single persons. Eisenstadt, 405 U.S. at 452-55.

96. The Supreme Court has restricted the traditional authority of parents to make medical decisions for their children because of the critical and urgent nature of the abortion decision and the potential conflict of interest between parent and child. See City of Akron v. Akron Center for Reproductive Health, Inc., 462 U.S. 416, $439-40$ (1983); H.L. v. Matheson, 450 U.S. 398, 405 (1981); Bellotti v. Baird, 443 U.S. 622, 643-44 (1979) (plurality opinion); Planned Parenthood v. Danforth, 428 U.S. 52, 74 (1976). In Bellotti, a plurality found that a minor was entitled to a judicial proceeding to show that she was "mature enough and well enough informed to make her abortion decision ... independently of her parents' wishes." Bellotti, 443 U.S. at 643. The Court has never defined "maturity," and commentators have speculated whether it connotes competency to make an informed medical decision, or some more general notion of maturity. See Scott, Adolescent's Reproductive Rights: Abortion, Contraception, and Sterilization, in Children, Mental Health and THE LAW 140 (1983). Even a young minor cannot be presumed incompetent to make her own decisions. In City of Akron, the Court struck down an ordinance requiring parental consent to abortion for minors under age fifteen. City of Akron, 462 U.S. at 452.

The Court acknowledged traditional parental interests, however, when it upheld a Utah statute requiring physicians to give notice to parents when they perform abortions on minors. Matheson, 450 U.S. at 411-13. Justice Powell, concurring, specifically left open the question whether this requirement would apply to mature minors. Id. at 414 .

97. See Danforth, 428 U.S. at 69.

98. Mill argued that the only appropriate reason for interfering with individual freedom is to avoid harm to others. He would not tolerate paternalistic intervention in decisions by "mature and rational human beings," even if the paternalistic act would protect one from self-harm. See J. MiLL, supra note 92 , at 77-79. He specifically excluded children, and by implication mentaily disabled persons. Id. at 22 ("Those who are still in a state to require being taken care of by others must be protected against their own actions as well as against external injury."). For commentary on the implications of Mill's philosophy for the mentally disabled, see Monahan, John Stuart Mill on the Liberty of the Mentally Ill: A Historical Note, 134 AM. J. Psychiatry 1428 (1977). See also Feinberg, Legal Paternalism, 1 CAN. J. PHIL. 105 (1971). Feinberg explains that autonomous actions and decisions must be "fully voluntary" and "chosen." Id. at 111 . Chosen actions require deliberation-a process that requires time, information, and highly developed rational faculties. Id. A deci. 
have challenged the presumption that mentally retarded persons are not able to make legally relevant decisions. ${ }^{99}$ Some observers have gone a step further and have suggested that disabled persons may benefit from the exercise of legal rights even if they do not fully comprehend the decisions they make. ${ }^{100}$

The law has come to reflect these changing attitudes in some respects. Mentally disabled persons are no longer presumed by the law to be incompetent, unless they are subject to a guardianship. ${ }^{101}$ Furthermore, some guardianship laws are structured so that the guardian has authority over only a limited range of decisions that are clearly beyond the capability of the disabled person. ${ }^{102}$

sion is not a chosen action if it is made without an understanding of its meaning and consequences. Id. at $110-11$.

Traditionally, mentally retarded persons were deemed incapable of making rational choices. Their decisions were not chosen and, hence, not autonomous. The use of a surrogate decisionmaker therefore did not violate autonomy. See T. Beauchamp \& J. Childress, Principles of BiomediCAL ETHics 63-64, 70-74 (1983). To the extent that the mentally disabled person is capable of rational choice, of course, autonomous decisions are possible and the traditional approach is invalid.

99. See, e.g., Wikler, Paternalism and the Mildly Retarded, 8 Phil. \& Pub. AfF. 377 (1979). Wikler asserts that relative intellectual inferiority does not provide a general justification for paternalistic intervention because otherwise the liberty of normal people could be restricted and they could be subject to the superior decisionmaking of the intellectually gifted. Id. at 380 . Other authors have criticized a general incompetency standard as applied to medical decisions. See C. LIDz, A. Meisel, E. Zerubavel, M. Carter, R. Sestak \& L. Roth, Informed Consent: A Study of Decisionmaking In Psychiatry 221 (1984); Meisel, The "Exceptions" to the Informed Consent Doctrine: Striking a Balance Between Competing Values in Medical Decisionmaking, 1979 WIS. L. REv. 413, 440-42.

100. John Garvey describes several theories that would justify ascribing constitutional freedoms (by which he means rights that involve choices) to persons with a limited capacity to make choices. Garvey, Freedom and Choice in Constitutional Law, 94 HARv. L. REv. 1756, 1762 (1981). Insofar as it ascribes freedoms without regard to competency in order to preserve human dignity, a laissez faire model offers the most expansive protection. Although Garvey does not support the laissez faire approach, he uses it to challenge traditional presumptions of incompetency. Id. at 1765 . He also identifies an instrumentalist approach, which emphasizes that the exercise of freedom may promote the individual's development and welfare. Id. at 1768. Garvey argues that a surrogate decisionmaker is needed if the choice involves significant risk or if the person is incapable of making any choice. The disabled person can exercise freedoms free from state interference through a surrogate who is close to the individual. Id. at 1778 . Only if a concerned surrogate is lacking is the individual subject to state authority.

101. Most laws provide that a court can appoint a guardian only after a competency hearing. The statutes make provision for notice, the right to counsel, and the right to cross-examine. See Minn. Stat. Ann. $\S \S 252$ A.03-.10 (West 1982); N.Y. Surr. Ct. Proc. Act $\S 1750$ (Supp. 1986); N.C. Gen. STAT. §§ 35-1.8 to 1.20 (1984); W. VA. CoDE $§ 27-11-1$ (1986), § 44-10A-1 (1982). For an overview and critique of plenary guardianship, see Frolik, Plenary Guardianship: An Analysis, a Critique and a Proposal for Reform, 23 ARIz. L. Rev. 599 (1981). See also Webster, A Study of Guardianship in North Dakota, 60 N.D.L. REv. 45 (1984).

102. For example, a limited guardianship may give the guardian authority only to make medical or financial decisions. See Minn. Stat. AnN. § 252A.11 (West 1982); N.Y. Surr. Ct. Proc. Act $\S 1751$ (Supp. 1986); N.C. GeN. STAT. § 35-1.34 (1984); W. VA. Code § 44-10A-2 (1982). For a good overview with an emphasis on limited guardianship, see Sherman, Guardianship: Time for a 
Broad presumptions regarding the incompetency of mentally disabled persons are not appropriate because competency can vary in two ways. First, competency can vary according to the person's level of impairment. The capacity of the mildly retarded person to make most legally relevant decisions may approximate that of a normal person. Second, competency will depend on the decision to be made; a given individual might be competent to make some decisions but incompetent to make others. ${ }^{103}$

Even for persons who are otherwise deemed incompetent, a presumption of incompetency is inappropriate when reproductive decisions are involved. The Supreme Court has recognized that individuals who are not legally autonomous for some purposes can nonetheless have a constitutionally protected interest in reproductive autonomy. The Court has consistently held that a minor who is capable of a mature abortion decision need not obtain the consent of her parents or the state. ${ }^{104}$ The traditional legal presumption favoring parental authority yields in this situation because of the importance of the child's interest in reproductive privacy and the potential conflict of interest between parent and child. A decision made on the minor's behalf by a surrogate decisionmaker is acceptable only if the minor is actually incapable of making her own decision.

In some sense, the retarded individual for whom sterilization is proposed is in a similar position. She might be capable of making the reproductive decision, even if she is subject to a guardianship for other purposes. ${ }^{105}$ Like the adolescent seeking abortion, the retarded individ-

Reassessment, 49 Fordham L. REv. 350 (1980). See also Note, Limited Guardianship for the Mentally Retarded, 8 N.M.L. REV. 231 (1978).

103. Thus, an individual might be capable of driving a car and managing simple finances, but incapable of making an informed medical decision. This suggests the importance of basing the determination about competency on an individualized assessment of the person's ability to make the specific decision or perform the specific function in question. Ruth Macklin and Willard Gaylin identify three variables as relevant to determining competency: (1) the type of decision, (2) age and transient emotional or motivational variables, and (3) potential for training for future competency.

R. MACKLIN \& W. Gaylin, supra note 26, at 59.

104. See supra note 96 . The comparison between minors and mentally disabled persons is instructive. Minors are subject to a blanket presumption that they are incompetent to make most decisions, but the restriction on minors' autonomy is of a limited duration and consequently the deprivation of rights may be less costly. Thus, individualized determinations regarding competency on most specific issues may simply be too cumbersome and inefficient. See generally Weithorn, Children's Capacities in Legal Contexts, in Children, Mental Health ANd THE Law 25 (1984).

The exception carved out for minors' abortion decisionmaking is justified in part because the decision cannot be postponed and it is critically important to the minor's life. Unlike most other health care decisions, the parents' objective cannot be presumed to be promotion of the health of the child.

105. Most current laws require a determination about the individual's competency to make the sterilization decision-regardless of whether she is subject to a guardianship. See supra notes 34-35. 
ual who is actually competent to exercise meaningful choice should have a legally protected interest in reproductive autonomy.

What then constitutes meaningful reproductive choice? Three distinct decisions are involved, each of which requires a different level of competency and intellectual functioning. First, a disabled individual may be capable of making a meaningful decision to have a child. Second, she may be competent to make the separate decision to forgo having a child. Finally, if she has competently made the basic reproductive decision, she may be capable of implementing that choice through an informed medical decision regarding sterilization or other forms of birth control.

The autonomy interest of the mentally retarded person in deciding whether to have a child is obscured under laws based on the paternalism model because of the requirement of a threshold inquiry into whether the person is competent to make an informed medical decision about sterilization. If she is not, the law presumes that she is incapable of making the reproductive decision and that a surrogate (the court) must weigh her interests and make the decision for her. ${ }^{106}$ The ability to make an informed medical decision involves a level of cognitive functioning that many mentally retarded persons lack. ${ }^{107}$ However, a person who is unable to make this implementing decision might nonetheless be capable of making the underlying decision to have or to forgo having a child. ${ }^{108}$ This decision is fundamentally different from the medical sterilization decision and requires different capabilities. By specifying competency to make the medical decision as the threshold requirement, laws based on the paternalism model distort and even foreclose the inquiry into the individual's ability to make the decision whether to have a child.

Under the autonomy model, competency to make a meaningful choice to procreate rests on the individual's ability to fulfill the basic responsibilities of parenthood. A mildly impaired person may have this ability regardless of whether she is legally competent to make medical decisions regarding sterilization. Her interest in making her own repro-

In a few states, a sterilization decision can be based on a general designation of incompetency. See In re Penny N., 120 N.H. 269, 271, 414 A.2d 541, 543 (1980).

106. See supra notes $34-35$ and accompanying text.

107. See supra note 26 and accompanying text; see also infra notes 112-18 and accompanying text (discussing cognitive capacity needed for medical decisionmaking).

108. My colleague Ken Abraham suggests that individuals who are unable to make medical decisions will not be competent parents because such individuals would be unable to make informed medical decisions for their children. The point is well taken; however, if a parent could accomplish all other critical parental tasks, some mechanism could be devised to compensate for this disability.

Moreover, the distinction between the two types of competency is useful for analytical purposes. The most important inquiry in determining the individual's interest in reproductive autonomy is whether she will ever want a child. The medical competency issue obscures this inquiry. 
ductive decisions should be legally protected. On the other hand, a severely disabled person's childlike wish for a baby does not signify a meaningful choice. A decision to have a child is, most importantly, a decision to become a parent-to assume a role that requires a minimal level of competency. If the individual lacks this capability and the state would predictably intervene to remove any child produced in order to protect it, then the choice to have a child is not a legally protectable exercise in personal autonomy. ${ }^{109}$ Thus, the interest in autonomy is derivative of the underlying interest in having children. If the retarded individual lacks the ability to exercise the substantive interest, she lacks the interest in making the choice. ${ }^{110}$

The disabled person also may be capable of making an autonomous decision not to have a child. She may clearly express a stable preference not to have a child based on a desire not to assume the burdens of pregnancy or the responsibilities of rearing a child. Unlike the decision to procreate, the decision to avoid pregnancy involves an underlying substantive interest that does not itself require a minimal level of competency. ${ }^{111}$ Thus, the ability to make the decision to avoid pregnancy rests solely on a capacity for rational decisionmaking and not on any underlying functional capability. Rationality may be measured by the clarity and consistency of the expressed preference not to have a child. The preference may be to prevent pregnancy in the immediate future or it may directly or indirectly reflect a desire not to have children.

The individual who is competent to make her own reproductive choice may also be competent to implement that choice by making the medical decision about sterilization or other contraceptive options. With respect to the contraception decision, her autonomy interest has two dimensions. First, the decision is an exercise of reproductive autonomy. She is making a decision about whether to permanently or temporarily prevent pregnancy through a chosen medical procedure. Second, the competent individual has an overlapping but distinct interest in maintaining control over health care decisions. She has an interest in weighing the benefits and risks to her health of various medical and surgical

109. In theory, a person who is incapable of parenting because of mental disability may be capable of making a "rational" decision to procreate reflecting a basic understanding of what it means to have a child - costs, benefits, risks, etc. That decision has little meaning, however, if she could never function as a parent. In reality, it is probable that few will lack the functional capability while possessing the cognitive decisional ability.

110. The underlying interest itself often defines the individual's interest in control over making the decision. For example, minors do not have the freedom to make the decision to marry because they are deemed incapable of assuming the responsibility of marriage. They lack the underlying substantive interest and therefore lack the interest in making the decision.

111. Indeed, avoiding pregnancy may promote the physical, psychological, and social welfare of a profoundly impaired person. See H. KAPLAN \& B. SADOcK, supra note 26, at 852. 
procedures and reaching a decision whether or not to undergo a given treatment. ${ }^{112}$ Applying the preferred legal standard, competency to give (or withhold) informed consent to a medical procedure is based on an appreciation of the nature and purpose of the procedure, its risks and benefits, and its consequences in comparison with available alternatives. ${ }^{113}$

Some individuals who are capable of making a meaningful reproductive decision will not be capable of making the medical decision necessary to implement the underlying choice. ${ }^{114}$ It has been suggested that informed medical decisionmaking requires the ability to engage in formal operational thinking. According to Piaget, this is the highest stage of cognitive development and is achieved by normal individuals between the ages of eleven and fourteen. ${ }^{115}$ At this stage one has the capability to conceptualize several abstract possibilities and consider the consequences of various courses of action. ${ }^{116}$ Many mentally disabled persons lack this capability and are thus unable either to appreciate the consequences,

112. Commentators have argued that the informed consent requirement for medical treatment is also based on protecting personal autonomy. The individual must understand the procedure, its risks, benefits, and alternatives in order to control what will be done to her body. See Capron, Informed Consent in Catastrophic Disease Research and Treatment, 123 U. PA. L. REV. 340, 364-76 (1974).

In a leading case defining the contours of modern informed consent law, Natanson v. Kline, 186 Kan. 393, 350 P.2d 1093 (1960), the Kansas Supreme Court stated: "Anglo-American law starts with the premise of thorough-going self-determination. It follows that each man is considered to be master of his own body, and he may, if he be of sound mind, expressly prohibit the performance of life-saving surgery, or other medical treatment." Id. at 406-07, 350 P.2d at 1104 .

113. There are several standards of competency to make medical decisions. Under the lowest standard, a competent individual is one who is capable of expressing a preference. A second standard focuses on whether the decision itself is rational; if it is, it is deemed competent. Some commentators have suggested that this standard is typically used in psychiatric hospitals. The decision to accept treatment is deemed competent; to refuse treatment suggests incompetency. See Meisel, supra note 99, at 443-45. A third standard looks at the rationality of the decisionmaking process. The fourth and prevailing standard is the so-called appreciation standard, which measures the patient's inferential as well as factual understanding or recall. See Weithorn, Developmental Factors and Competence to Make Informed Treatment Decisions, ChILdREN \& Youth Services, SpringSummer 1982, at $85,89-95$. Several commentators have suggested that appreciation requires the ability to think abstractly and draw inferences about the implications of the proposed treatment. See Applebaum \& Roth, Clinical Issues in the Assessment of Competency, 138 AM. J. PSYCHIATRY 1462, 1463-65 (1981); Weithorn, supra note 104, at 35.

114. The Forensic Psychiatry Clinic at the University of Virginia, for example, evaluated a woman, B., age 35 with one child, who had over a number of years consistently said that she wanted "no more babies." Attempts to use birth control pills and an IUD had caused substantial medical problems. Her competency to make the sterilization decision was questionable, however, because she could not think abstractly about permanence and about not being able to change her mind in the future.

115. See H. Kaplan \& B. SAdock, supra note 26, at 58-59.

116. See Weithorn, supra note 104, at 37. Weithorn and Campbell conducted research on the competency of normal children to make medical decisions. They found that, by age 14, minors reasoned about medical decisions much like adults. See Weithorn \& Campbell, The Competency of 
risks, and benefits of sterilization or to weigh the alternatives. ${ }^{117}$ If the individual is incapable of giving informed consent to contraceptive treatment, her reproductive decision may be undermined. ${ }^{118}$ Therefore, the law should facilitate her reproductive choice through a surrogate who can consent to the medical procedure for her.

The retarded person who is competent to make autonomous reproductive and medical decisions should not be subject to paternalistic supervision. In light of the overriding interest in personal autonomy, the individual should be free to weigh whatever other interests are subjectively important to her, regardless of what an objective decisionmaker would consider to be in her best interest. For example, she is free to choose to have a child even if a medical condition makes this decision risky. If her decision is competent, its wisdom should not be scrutinized.

4. Summary. In contrast to the paternalism model, the autonomy model defines the interest in reproductive autonomy both more precisely and more expansively by focusing on the person's capability to make the reproductive choice. The mentally retarded person has an interest in reproductive autonomy if she is capable of making a meaningful decision about whether or not to have a child. Her interest in a meaningful choice to procreate is derived from her substantive interest in reproduction. If she is capable of rearing a child, her interest in procreation and in the decision to have children is indistinguishable from that held by the normal person. Her interest in the decision not to have children rests on her ability to make a meaningful choice to avoid pregnancy. The individual who is capable of making an autonomous reproductive choice might or might not be capable of making the implementing medical decision; this requires the cognitive ability to give or withhold informed consent to the medical procedure.

Children and Adolescents to Make Informed Treatment Decisions, 53 CHILD DEV. 1589, 1595-96 (1982); see also supra note 26.

117. Persons who are more than mildly retarded are unlikely to have this capability. It is unclear whether mildly retarded persons would be able to engage in these cognitive processes. See R. MACKLIN \& W. GAYLIN, supra note 26, at 59-62. The cognitive developmental approach to mental retardation suggests by definition that mentally retarded persons do not reach the highest stage of cognitive development-formal operational thinking. See supra note 26 and accompanying text. I am reluctant to engage in such a broad categorization, however, given the variations in conceptualizing both mental retardation and competency.

118. The individual described supra note 114 is a good example. Sterilization was not allowed because she was capable of caring for her child, and thus could not meet one of the mandatory criteria under Virginia law. See VA. CodE ANN. § 54-325.13(4) (1982). 


\section{B. Residual Interests of the Severely Retarded Person.}

Some mentally disabled persons are not competent to make reproductive decisions for themselves. A decision about sterilization made on behalf of an individual in this category violates no interest in reproductive autonomy; when a person is incapable of making her own decision, others must determine whether sterilization is in her best interest. ${ }^{119}$ Sterilization is not necessarily the appropriate choice simply because the individual has no meaningful interest in reproduction, and therefore has a presumptive interest in avoiding pregnancy. The desirability of the procedure may depend on nonreproductive considerations such as medical risks and benefits, human dignity, privacy, and family continuity and stability.

1. Medical Risks and Benefits. The person who is unable to make her own medical decisions has an interest in a decision about contraception that most effectively promotes her medical needs. Risk, convenience, comfort, intrusiveness, and effectiveness are variables that may be relevant in treatment choice. One option is long-term use of birth control pills. However, this practice is generally not advised for normal women; its medical risks are now being studied. ${ }^{120}$ Use of an intrauterine device also entails substantial risk; ${ }^{121}$ indeed, most models have been

119. The term "best interest" is often associated with a judicial decisionmaker exercising the state's parens patriae authority. This article uses the term to encompass decisions by parents as well. The law's objective is for the decisionmaker, whether court or parent, to make the sterilization decision that is best for the incompetent person.

120. Oral contraceptives such as the Pill must be taken on a regular schedule and may present several risks to the user including heart disease, diabetes, thrombophlebitis, and hypertension. See Contraceptive Technology, supra note 1, at 49-50, 56-61. But see Sattin, Rubin, Wingo, Webster \& Ory, Oral Contraceptive Use and the Risk of Breast Cancer, 315 NEw ENG. J. MED. 405 (1986) (study finding no correlation between long-term use of oral contraceptives and breast cancer). Minor side effects such as weight gain and frequent headaches are also possible. See ConTRACEPTIVE TECHNOLOGY, supra note 1, at 55-56.

121. IUDs are inserted into the uterus and prevent an embryo from attaching to the uterine wall. The principle risks associated with IUDs are: discomfort, increased bleeding, spontaneous expulsion, increased frequency of urine and pelvic infection, and pregnancy failures. See CONTRACEPTIVE TECHNOLOGY, supra note 1, at 202-10.

Concerns about the safety of the IUD have grown in recent years and the device may not be available in the future. Some commentators feel that for nulliparous women (women who have never been pregnant), the use of an IUD may double the risk of tubal infertility in comparison with other methods of contraception. See Cramer, Schiff, Schoenbaum, Gibson, Balisle, Albrecht, Stillman, Berger, Wilson, Stadel \& Seibel, Tubal Infertility and the Intrauterine Device, 312 Nrw ENG. J. MED. 941, 947 (1985). A.H. Robins, Inc., producer of the Dalkon Shield, has incurred massive liability in a class action settlement with women seriously injured by this device. Robins filed a Chapter 11 bankruptcy petition after incurring liability of $\$ 1.1$ billion in litigation costs with 5,000 suits pending. Another manufacturer of IUDs, G.D. Searle \& Co., is facing potentially disastrous litigation. Over 600 suits were pending as of October 1985. See Glaberson, Did Searle Close Its Eyes?. Bus. WK., Oct. 14, 1985, at 120. Both Searle and Ortho Pharmaceutical Corp. have removed 
withdrawn from the market. This risk is increased if the physician uses a general anesthetic while inserting the device (a common practice with severely retarded women because the patient may otherwise resist the procedure). ${ }^{122}$ The experimental drug Depo-Provera is another form of contraception used for retarded women. ${ }^{123}$ Again, the effects of longterm use are unclear. Finally, if ineffective (perhaps less risky) birth control options are chosen, the risks associated with pregnancy, abortion, and childbirth must be considered. ${ }^{124}$ None of these contraceptive options is a clearly superior medical alternative to salpingectomy or other nonintrusive forms of sterilization. ${ }^{125}$ Thus, the individual's interest in the optimal medical decision may be promoted as well by nonintrusive forms of sterilization as by the available contraceptive alternatives.

Laws based on the paternalism model fail to separate the individual's reproductive interest from her interest in the medical decision. Be-

their IUDs from the market. The only IUD currently being sold in the United States is a little-used device that releases hormones in much the same way as the Pill. Dulea, Liability Crisis Complicates Contraception, N.Y. Times, May 19, 1986, at B8, col. 1.

122. Insertion of an IUD may be difficult with a retarded woman as some pain is involved, which she may not understand. Some gynecologists use general anesthesia when performing this procedure because of concern that perforation or other injury will result if the woman is agitated. See Melton \& Scott, Evaluation of Mentally Retarded Persons for Sterilization: Contributions and Limits of Psychological Consultation, 15 Prof. Psychology: Res. \& Prac. 34, 42 (1984).

Professors La Veck and de la Cruz, writing before the risks of IUDs became known, recommended the IUD as the optimal contraceptive option for mentally retarded women since it requires no motivation or intellectual skills. See La Veck \& de la Cruz, Contraception for the Mentally Retarded: Current Methods and Future Prospects, in Human SeXuality and the Mentally ReTARDED 96-97 (F. de la Cruz \& G. La Veck eds. 1973).

123. Depo-Provera is a substituted progesterone that suppresses ovulation. It is effective for three months when injected intramuscularly. The Food and Drug Administration has not yet approved Depo-Provera for contraceptive use in the United States because it causes breast tumors in beagles. See R. Hatcher \& G. Stewart, Contraceptive Technology 1982-1983, at 66-67 (1982). Use of the drug also causes minor side effects such as disruption of normal menstruation and irregular and unpredictable bleeding. The woman may experience weight gain and a delayed return of fertility once treatments are stopped. See id. at 67.

124. The medical risk, pain, and anxiety associated with pregnancy and birth may be greater for one who does not understand the process and cannot look forward to the fruits of the effort. Abortion has some risks that increase as the term of the pregnancy progresses. Second trimester abortions have risks comparable to the risks of childbirth. See id. at 7 . For teens, childbirth has five times the mortality/morbidity rate of a first trimester abortion. Id.

125. Some forms of tubal ligation may be performed on an outpatient basis. It leaves minute scars, involves minimal discomfort, and allows for a rapid recovery with a quick return to normal activity, including sex. The most popular form of tubal ligation is laparoscopy, which involves extremely rare risks of hemorrhage, electric shock, perforation of organs, puncture of blood vessels and skin, and internal burns. The current mortality rate for the laparascopic procedure is 10 deaths per 100,000 procedures. See id. at 195-96.

The only complications associated with vasectomy, an outpatient procedure, are skin discoloration, swelling, pain, and hematoma (a mass of clotted blood from injured blood vessels in loose connective tissues of the scrotum). Hematomas usually occur in less than one percent of all vasectomies. See id. at 190. 
cause sterilization extinguishes reproductive capacity, it is presumed to be inherently more intrusive and "drastic" than any nonpermanent form of contraception, and is only allowed as a last resort. However, for the person who has no interest in having children, some forms of sterilization are no more "drastic" in a medical sense than other contraceptive options. For the severely disabled person who lacks a potential interest in having children, assessment of sterilization as a treatment alternative should be made independently of the interest in reproduction itself.

However, more intrusive forms of sterilization, such as hysterectomy, are not comparable in a medical sense to other contraceptive options. Some parents might seek hysterectomy ${ }^{126}$ for a severely retarded daughter because she has difficulty managing menstrual hygiene tasks or because she experiences distress with menstrual periods. ${ }^{127}$ In this situation, the threat to the retarded person's interest in the optimal medical decision is greatly increased because the procedure is major surgery and involves enhanced medical risk. Furthermore, medical judgment may not serve its traditional protective function. Physicians can generally be relied on to recommend the treatment that best promotes the patient's medical welfare with minimal risk. However, a gynecologist might recommend a hysterectomy for a severely retarded young woman, based not on the woman's gynecological needs, but on an evaluation of her intellectual capabilities, an issue on which gynecologists have little expertise. To the extent that risk is incurred beyond that indicated by her medical needs, intrusiveness is increased and justification of the decision on the ground that it promotes the patient's interests becomes more difficult. ${ }^{128}$

126. Although hysterectomy is $100 \%$ effective as a method of birth control, some authorities flatly state that because of the risks, hysterectomy is never appropriate for contraceptive purposes. See Amirikia \& Evans, Ten-year Review of Hysterectomies: Trends, Indications, and Risks, 134 AM. J. OBSTETRICS \& GyNecology 431, 432-33 (1979) (study of 6400 hysterectomies described significant complications including infection $(4.7 \%)$, bleeding $(1.4 \%)$, risks from transfusion (12\%), bladder and bowel injury $(0.6 \%)$, thromboembolisms $(0.6 \%)$ and death $(0.26 \%)$ ). Usually hysterectomies are only performed for sterilization purposes when there are other gynecologic problems present as well. See M. Saidi \& C. Zainie, Female Sterilization: A HandBook for WOMEN 44 (1980). Many current laws implicitly discourage hysterectomies by requiring that the sterilization procedure chosen be the least restrictive alternative. See, e.g., VA. CodE ANN. $\S 54-$ 325.12 (1982).

127. Research indicates that moderately retarded persons with proper training can manage all aspects of menstrual hygiene. Severely retarded women can learn all aspects except initiation. See Hamilton, Allen, Stephens \& Davall, Training Mentally Retarded Females to Use Sanitary Napkins, Mental. Retardation, Feb. 1969, at 40, 43; see also Melton \& Scott, supra note 122, at 42-43.

128. A major surgical procedure with significant medical risk may be medically necessary to save the person's life or restore her health. It is the discrepancy between the nonautonomous patient's medical needs and the risk associated with the procedure that raises concerns about whether her welfare is promoted.

An analogous problem arises in medical research on incompetents and children. If an individual is not competent to consent to the risks of research, the procedure may represent an unwarranted 
2. Human Dignity and Privacy. The severely disabled person who is incapable of autonomous choice has an interest in being treated with human dignity and in avoiding unnecessary intrusions into her privacy by those who make the sterilization decision for her. ${ }^{129}$ Her dignity interest is threatened if she is subjected to a medical procedure against her will. Furthermore, protection of privacy requires that personal inquiry and disclosure in the decisionmaking process be limited, and that only those persons whose participation is needed to make a good decision be involved. ${ }^{130}$

Some individuals who are not capable of making their own reproductive decisions will object to a proposed sterilization. Such objection can reflect varying levels of comprehension and may have several sources. The individual might adhere to a childlike wish for a baby. She might be afraid of doctors, hospitals, or pain. Whatever the source of her protest, the medical procedure will be more offensive to her dignity then if she were agreeable. In general, any objection reflecting basic understanding signifies that the procedure intrudes on the individual's dignity. Although the protest should not necessarily determine the outcome, it does reflect an interest of the individual that should be considered in any decision designed to promote her welfare. ${ }^{131}$

In general, the severely retarded person has a reduced expectation of personal privacy. Others are involved in intimate decisions affecting her life, including medical decisions, to a greater extent than is the case with the normal person. Even if she is capable of making her own decisions,

bodily intrusion because its purpose is not solely health promotion. See Kaimowitz v. Michigan Dep't of Mental Health, 42 U.S.L.W. 2063, 2063 (Mich. Cir. Ct. July 10, 1973) (involuntarily committed patient cannot consent to experimental "high risk-low benefit" psychosurgery).

129. The notion of "respect for persons" extends beyond respect for individual autonomy to a recognition of the humanity of nonautonomous persons. In Kantian terms, persons should not be treated as a means to another end. See T. Beauchamp \& J. Childress, supra note 98, at 7.

130. The Supreme Court has described two dimensions of the right of privacy: independence in making important personal decisions, and freedom to prevent disclosure of personal facts. See Whalen v. Roe, 429 U.S. 589, 599-600 (1977). The incompetent person lacks the first dimension, but this does not mean that the second dimension should routinely be disregarded. Many current laws require judges, attorneys, and others to scrutinize the mentally retarded person's competency, parenting ability, sexual activities, reproductive capacity, and contraceptive practices. See supra notes 35-48 and accompanying text. Such scrutiny is justified only if it serves some beneficial purpose.

131. Federal regulations governing medical research involving children recognize that an incompetent person's agreement or objection to a medical procedure may be significant. See 45 C.F.R. $\S \S 46.401-.409$ (1985). These regulations require the parents' permission and the minor's assent for most types of research. Assent is not defined, but Professor Weithorn has described it as knowledgeable agreement. Weithorn, Children's Capacities to Decide About Participation in Research. IRB, Mar.-Apr. 1983, at 1,2. Weithorn suggests that children become capable of assent at age six. Id. at 5. If a child capable of assent protests, the protest will be respected unless the research offers the child a direct health benefit that is otherwise unavailable. 45 C.F.R. $\$ 46.408$ (a) (1985). 
she will be allowed to do so only after intrusive scrutiny of her competency. ${ }^{132}$ Although most medical decisions will involve only her parents or guardian and a physician, the sterilization decision often involves an expanded group of participants. The potential for infringement of her privacy interest is great if the law requires rigorous procedural protections and substantive findings. ${ }^{133}$ Under the paternalism model, both individual and family privacy are largely ignored in the process of evaluating the desirability of sterilization. Although some intrusion on privacy is necessary, this interest should not be unnecessarily sacrificed. ${ }^{134}$

\section{The Interest of the Retarded Person in Family Stability. Many} parents abandon or institutionalize their mentally retarded children when the disability becomes apparent or burdensome; ${ }^{135}$ others place their children in foster care. The disabled person whose parents have accepted the responsibility of caring for her at home is very likely better off than one subjected to any of these alternatives; she has a substantial interest in continued care by her parents. Family stability is thus an interest held by the child as well as the parents. This stability may be affected by the level of stress that attends the burden of caring for a retarded child. ${ }^{136}$ It can be threatened by concerns about the child's sexuality. The welfare of a severely retarded person who has no interest in reproduction may be promoted if her parents' concerns about pregnancy

132. Note the parallel here to the procedures set forth in Bellotti v. Baird, 443 U.S. $622,643-44$ (1979) (plurality opinion), for determining the maturity of the minor who seeks an abortion. For a discussion of Bellotti, see supra note 96.

133. See supra notes $37-50$ and accompanying text.

134. Application of the least restrictive alternative doctrine is relevant to intrusions into personal privacy. See Hoffman \& Foust, Least Restrictive Treatment of the Mentally Ill: A Doctrine in Search of its Senses, 14 SAN Diego L. Rev. 1100, 1102-03 (1977). Any infringement of a constitutionally protected interest should be restricted to that necessary to accomplish the legitimate purpose. Id. at 1101. This doctrine has been applied to involuntary treatment of mentally ill patients. Id. at 1102 . Civil commitment law in many states includes a directive that the least restrictive treatment be utilized. Id. at 1112 .

135. The normalization trend has encouraged parents to rear their mentally retarded children at home. See supra note 28. Nonetheless, family stress may increase as the child grows older, and may ultimately prompt a decision to remove the child from the home. For boys, concern among neighbors about aggressiveness may be a problem. See E. Schulman, supra note 26, at 100. For girls, the parents' dominant concern may be pregnancy.

136. For a discussion of the stresses involved for parents and siblings who live with a retarded child, see E. Schulman, supra note 26, at 96-125. See also J. Greenfeld, A Child Called NOAH: A FAMILY JourNey (1972) (personal account of father of autistic child). Families with a mentally disabled child frequently experience marital and financial stress. See Dunlap \& Hollinsworth, How Does a Handicapped Child Affect the Family? Implications for Practitioners, 26 FAM. COORDinator 286 (1977); Sherman \& Cocozza, Stress in Families of the Developmentally Disabled: A Literature Review of Factors Affecting the Decision to Seek Out-of-Home Placements, 33 FAM. REL. 95 (1984). 
are alleviated. Her interest in family stability is substantial and therefore may warrant legal protection.

The individual's interest in family stability should become legally relevant with respect to the sterilization decision only if the individual is so seriously impaired that she will never be capable of making her own reproductive decisions. For example, a mildly retarded young woman whose parents respond to her promiscuous behavior by seeking sterilization might have an interest in reducing family stress; if sterilization is proscribed, her parents might respond with abusive treatment, unreasonable restrictions of her freedom, or even relinquishment of their parental role. However, this young woman will one day be independent and might at that time want to have children. ${ }^{137}$ Thus her future capability to make decisions for herself precludes legal consideration of her present interest in family continuity. Using sterilization to promote family stability is as offensive here as it would be in the case of a promiscuous normal adolescent.

\section{The Autonomy Model and the Deficiencies of Current Law.}

The analytic framework developed in this Part suggests that current law falls short of its objective of promoting sterilization decisions that reflect the interests of mentally disabled persons. The preoccupation with correcting the abuses of the past in combination with a superficial analysis of the interests at stake has engendered significant distortions. Three problems result from the paternalism model's presumption that the primary interest at stake is the interest in procreation. First, in its effort to protect the mentally retarded person from wrongful sterilization, the law unduly restricts her right of self-determination. As I have shown, if only persons competent to make the medical decisions are deemed capable of making reproductive decisions for themselves, some persons who do have an interest in autonomy will find themselves subject to the authority of another decisionmaker. That is, an individual who is capable of deciding the more basic issue-whether or not to have a child-will sometimes, in the name of protection, be subject to a surrogate decisionmaker.

137. This situation was presented in Stump v. Sparkman, 435 U.S. 349 (1978). In that case, a mother, prompted by concern over her teenage daughter's promiscuity, successfully petitioned a judge for the daughter's sterilization. The daughter was described as "somewhat retarded," although she was promoted each year with her public school class. Id. at 351. She was told that the surgical procedure was an appendectomy and did not learn that she had been sterilized until she married and found that she was unable to become pregnant. Id. at 353. The daughter sued her mother and the judge who authorized the procedure. The Supreme Court upheld the judicial immunity of the judge, who had authorized the sterilization absent statutory authority. Id. at 364 . 
Second, laws based on the paternalism model treat sterilization as an infringement of the right to procreate rather than as a means of exercising the right not to procreate. ${ }^{138}$ It is ironic that a legal rule designed to protect mentally disabled persons impairs the fundamental right to avoid pregnancy-a right that others can exercise freely. Laws premised on a strong presumption that every retarded person has an interest in procreation make consideration of the interest in avoiding pregnancy very difficult in some cases.

Finally, current law ignores the interest in family stability that the severely disabled person shares with her parents. Under the paternalism model, the parents' interest in convenience, reduced anxiety, and family stability is not only deemed irrelevant to the decision, but is presumed to conflict with the child's interest. This presumption is valid if an interest in procreation exists. If no such interest exists, however, ignoring the importance of family stability for the severely retarded person may well lead to a decision contrary to her best interest.

The analysis proposed here offers an alternative conception of the interests of the mentally retarded person for whom sterilization is proposed. The autonomy model defines the interests of the mentally disabled person in making her own reproductive decisions more broadly and more precisely than does the paternalism model. The competent person's interest in independent decisionmaking rests on her ability to make the underlying reproductive choice, whether or not she can implement that choice through a medical decision. The model suggests that the individual who is not capable of making autonomous reproductive decisions has an interest in preserving family stability, and that this interest will be promoted by state deference to parental authority. ${ }^{139}$ Thus, in contrast to the paternalism model, which offers elaborate substantive criteria, the autonomy model identifies the correct allocation of decisionmaking authority as the means of advancing the retarded person's interests. The autonomy model indicates that the interests of the mentally retarded person will be best protected by a legal rule that limits protective state intervention and supports private decisionmaking by the individual or, if she is incompetent to make the reproductive decision, by her parents. The next Part examines the implications of the autonomy model for the formulation of an optimal legal rule.

138. See supra note 50.

139. The person incapable of making her own choices has an interest in having parents make decisions for her and in avoiding state interference. In analyzing the child's interest in parental authority under the constitutional family privacy doctrine, Garvey aptly asserts that "[c]onstitutional liberties protect children in the exercise of choices that their parents have made for them." Garvey, supra note 100 , at 1782 . 


\section{Application of the Autonomy Model}

\section{A. Protecting Meaningful Choice-The Retarded Person as Decisionmaker.}

Devising a legal rule that protects the expansively defined autonomy interest of the competent retarded individual is more difficult than it might first appear. The autonomy model suggests that three separate inquiries are relevant: an inquiry into the individual's competency to make the decision to have children, an inquiry into her competency to avoid pregnancy, and an inquiry into her competency to elect sterilization.

The examination of competency is further complicated in this context by the unique relevance of the person's future competency and interest in autonomous choice. Because sterilization extinguishes reproductive capacity and moots the issue of reproductive choice, the law should preserve the disabled person's potential interest in making her own decisions if she might become competent in the future. Thus a determination of incompetency may require an evaluation of future functioning that is necessarily speculative in nature.

Because incompetency may be due to developmental factors, potential competency is particularly important if the mentally retarded person is a minor. To guard against error, sterilization might be restricted to adults. ${ }^{140}$ However, because severely retarded minors have a strong interest in family continuity, they may particularly benefit from legal support for parental authority; a policy that proscribes their sterilization may not serve their interests. Despite uncertainty, it is possible to make a determination that some severely disabled minors will never have the capacity to make reproductive decisions independently.

A person also has an interest in preserving future options if she is competent but currently has no expressed preferences. Thus, the retarded person who is potentially a capable parent should not be sterilized on the ground that she has expressed no desire for children. Only her stable long-term desire not to have children should be implemented through sterilization.

When parents propose sterilization for a mentally retarded child, an evaluation by an expert in mental retardation is necessary. One source of erroneous sterilization decisions in the past was reliance on the attending physician's opinion that sterilization was medically appropriate. This

140. In most states, normal minors may not obtain sterilization because of the permanency of the procedure. Sterilization laws directed at mentally disabled persons require a determination of future incompetency, see supra note 34 , thereby distinguishing the mentally retarded minor from other presumably incompetent normal minors. 
physician was usually a gynecologist with little or no expertise in assessing the functional capabilities of mentally disabled persons. Some current laws attempt to remedy this problem by requiring psychiatric, psychological, or "social" evaluation of the retarded individual. ${ }^{141}$ However, little guidance is given regarding the focus of the evaluation or the required expertise of the evaluator. Most physicians, including psychiatrists, have very limited expertise in mental retardation; most psychologists have only marginally more. A specific designation of expertise and training in mental retardation would promote more accurate assessments of competency than are likely to result under current law.

The determination of whether the disabled individual has the ability to make her own reproductive decisions should begin with an evaluation of her interest in procreation. Then, if she does not want children, the competency of this choice must be assessed. If her decision to avoid pregnancy is competently made, further inquiry is necessary to determine whether she is capable of making the informed medical decision to implement her reproductive choice. The discussion that follows examines the implications of positive and negative findings of competency.

\section{Parenting Capacity and Reproductive Choice. The autonomy} model presumes an interest in procreation, unless the individual would be so limited in her parenting ability that the state would be justified in terminating her parental rights should she ever have a child. Thus, under the autonomy model, the individual who is capable of functioning as a minimally adequate parent will not be sterilized unless she competently chooses never to have children. Making a determination about parenting ability will admittedly be difficult unless the person has had substantial experience being with children. ${ }^{142}$

A person has the minimal capacity to function as a parent if she would be able to meet a child's most basic needs. Thus, a parent must be able to understand the child's basic nutritional requirements and protect

141. See supra note 38 .

142. The assessment of present competency to make a decision is potentially a highly reliable judgment. It can be compared with determinations about competency of criminal defendants to stand trial. See R. Roesch \& S. Golding, Competency to STand Trial (1980). Much more uncertain are evaluations that predict how someone will function or act in the future. See J. Monahan, Predicting Violent Behavior: An Assessment of Clinical Techniques (1981); Melton \& Scott, supra note 122, at 39.

Several types of inquiry may be useful in assessing potential parental competency. An assessment of the person's actual and potential ability to care for herself is important because the person who cannot provide for her own nutritional, health, and safety needs cannot assume responsibility for another person. The individual's experience in caring for her own children, her siblings, or neighborhood children is also significant. Problem-solving hypotheticals involving typical child care issues may also be useful. 
the child from physical harm. She must be able to discern illness and know how to obtain medical help; she should also be able to express affection and provide adequate supervision of the child's daily routine.

The retarded person's interest in having children, however, should not be contingent on her ability to perform other functions usually associated with being a "good" parent. ${ }^{143}$ If she must demonstrate a more sophisticated capability to provide intellectual stimulation or meet the child's emotional needs, she will be subject to standards of competency in parenting that are not applied to others. Although good parents typically provide an intellectually stimulating environment, many normal parents do not. Horizontal equity thus dictates that nothing more than a standard of minimal adequacy be required.

The individual who is not capable of functioning as a parent has no interest in procreation and the choice to have children is not available to her. Arguably, she might have the capability to choose among alternatives for avoiding pregnancy; if so, her competent preferences should be respected. It is unlikely, however, that a person who is incapable of being a minimally adequate parent because of mental retardation will have the cognitive ability to consider contraceptive alternatives and make an informed medical decision. ${ }^{144}$ If she is incompetent, a decision will be made for her by her parents or (in some cases) by a court.

\section{Protecting the Decision to Avoid Pregnancy: Reproductive Choice} and the Medical Decision. A mentally disabled person may clearly and unambiguously express a desire not to have children. If she understands the implications of the decision and if it is made without coercive influence, her expressed preference should be respected by the law as a com-

143. The findings of research assessing the parental capability of mentally disabled persons are mixed. This research involves only parents who are mildly or moderately retarded. Some observers have suggested that the children of mentally retarded parents may suffer from a lack of intellectual stimulation. See E. SChulman, supra note 26 , at 302 . An early study of mentally disabled parents found that $42 \%$ provided adequate care for their children's physical needs, $32 \%$ provided marginal care, and $26 \%$ provided care warranting removal. See Mickelson, The Feebleminded Parent: A Study of 90 Family Cases, 51 AM. J. Mental Deficiency 644, 645 (1947). Some researchers have observed that although mentally retarded parents may not provide care meeting "middle class" standards, most do provide adequate care. See Murphy, Coleman \& Abel, Human Sexuality in the Mentally Retarded, in TREatment Issues and InNOvations in MENTAl Retardation 615 (J. Matson \& F. Andrasik eds. 1983).

Support services may be available to provide parents with training and assistance. See Mickelson, supra, at 644 . Rosenberg and McTate reported that mildly retarded persons who participated in parent training programs were able to improve their parenting skills. Rosenberg \& McTate, supra note 30 , at 24,37 .

144. If such a hypothetical person existed, her interest might be characterized as an interest in controlling the health care decision, rather than an interest in controlling the reproductive decision. In any event it would be a restricted exercise of autonomy since she is not free to choose the alternative of having children. 
petent and meaningful reproductive choice. Evaluation of the competency of this decision should focus on the consistency, clarity, and stability of the expressed choice and on the extent to which the decision is an independent one.

If the disabled person is found to be making a meaningful decision to terminate permanently her ability to have children, an examination of her competency to make an informed medical decision regarding sterilization should follow. The predominant standard defining competency to make medical decisions, and the one applicable to sterilization decisions, is the appreciation standard. ${ }^{145}$ This standard requires an inquiry into whether the individual has an inferential and factual understanding of the procedure's purpose, consequences, risks, and benefits, as well as an appreciation of the contraceptive alternatives available to her.

The evaluation of competency should focus on the person's understanding of the following: (a) the contraceptive purpose of sterilization, (b) the nature of the procedure (the incision, hospitalization, use of anesthesia), (c) the permanence of reproductive incapacity following sterilization, (d) the risks associated with the procedure (pain, possible infection or other complications), and (e) the availability and important characteristics of nonpermanent forms of contraception. ${ }^{146}$ The individual must be provided with sufficient information about the proposed sterilization to make an informed decision; a finding of incompetency should be based not on a lack of knowledge, but only on incapacity to understand the necessary information.

The doctrine of informed consent requires that the decision be voluntary as well as competent and informed. ${ }^{147}$ Given the potential conflict of interest between parent and child, the dependence of the individual on her parents, and the observed suggestibility of retarded persons, parental overbearance may be a significant possibility. Therefore, the independence of the individual's preferences as well as the extent to which her choices have been influenced by others must be determined.

A determination regarding the individual's competency to make the medical decision should be made as accurately, but as unobtrusively, as possible. A nonjudicial review of the finding that the person has competently decided on sterilization may often be desirable; however, it should be undertaken in such a way as to minimize intrusion into the person's

145. See supra note 113 and accompanying text.

146. See Melton \& Scott, supra note 122, at 38-39. The most critical factor and the one most mentally disabled persons are unlikely to understand is irreversibility. See infra note 149.

147. See Meisel, Roth \& Lidz, Toward a Model of the Legal Definition of Informed Consent, 134 AM. J. PSYCHIATRY 285, 286 (1977). 
privacy. ${ }^{148}$ Further inquiry is warranted only if competency to make the medical decision is questionable.

Some persons may be capable of making a competent decision not to have children but incapable of making an informed medical decision. A person who is unable to think abstractly about decisionmaking in the remote future might not fully understand that sterilization results in permanent infertility; she may, however, have unambiguously stated over an extended period of time that she does not want to have children. This person may be making a meaningful reproductive choice never to have children; the inference can be drawn that permanence is desired. Nonetheless, in those states that follow the paternalism model, her inability to understand the concept of permanence would preclude a competent medical decision and thus foreclose the possibility of sterilization, particularly if she already has children. ${ }^{149}$

3. Protecting Against Erroneous Decisions. The more expansive recognition of the autonomy interest of retarded persons under the autonomy model may arguably increase the risk of erroneous decisions to sterilize. The acquiescent or well-coached person might erroneously be characterized as making a meaningful decision to opt for sterilization. An error of this kind is particularly costly if the person has an interest in procreation. ${ }^{150}$

A few safeguards will reduce this risk. A comprehensive evaluation of the individual's decision by an expert in mental retardation is essential. ${ }^{151}$ If the person is incompetent to make the medical decision, a determination that sterilization is the optimal means of implementing her competent reproductive choice should be made. If she is potentially a competent parent, sterilization is usually appropriate only if a normal person in similar circumstances would choose this alternative. ${ }^{152} \mathrm{~A}$ mechanism should be provided to review the findings of competency and to determine the appropriateness of sterilization to implement the choice. Given the reproductive interest at stake, a judicial proceeding may be warranted. A less costly and less intrusive alternative would be review

148. See supra notes $129-30,174$.

149. For example, the patient described supra note 114 had consistently said for years that she wanted "no more babies." There was no indication that she would ever change her mind. She could not, however, think abstractly and hypothetically about how she might feel in the distant future. When asked "What if you should change your mind in ten years?," she would only repeat the assertion that she wanted a boyfriend and "no more babies."

150. See supra note 90 .

151. Many current sterilization laws require evaluation by an expert. See supra note 38 .

152. See supra notes 83-87. 
by a committee modeled on a hospital ethics committee. ${ }^{153}$ Finally, since informed consent to the medical procedure must be provided by some competent person, the parents' consent should be required.

4. Summary. When parents seek to have their child sterilized, an expert in mental retardation should examine the child and assess her capacity to make reproductive choices for herself. First, the expert should assess her interest in having children. If she has the ability to provide minimally adequate care for a child, no further inquiry is needed; sterilization should be proscribed unless she expresses a clear and independent preference not to have children. If she lacks an interest in procreation, the choice to have children will be unavailable to her. In most cases, a decision will be made for her as an incompetent.

If the individual expresses a preference not to have children, the second stage of inquiry begins with an examination of her capacity to make this decision autonomously. If her preference represents a rational choice, examination of her ability to make the implementing informed medical decision should follow. If she is competent, she should be treated like a normal person. If she is not, further assessment may be needed to probe the stability and consistency of her decision and to determine whether sterilization represents an appropriate medical response. Some independent review of these latter decisions is advisable.

\section{B. The Incompetent Individual: Who Decides?}

Analysis under the autonomy model indicates that the range of individuals who are competent to make reproductive decisions is broader than current law recognizes. Some persons, however, will have no interest in procreation and will be unable to make their own reproductive choices. Under the paternalism model, they will be subject to courts as decisionmakers; their parents are legally disqualified because of a presumed conflict of interest. The autonomy model indicates that the se-

153. For a discussion of the function of hospital ethics committees and the recommended role of this type of committee when parents make decisions for incompetents, see infra note 174 and accompanying text.

There are three situations in which some kind of independent review of the competency determination may be indicated:

1) The retarded person is found competent to make the medical decision and chooses sterilization.

2) The retarded person is found competent to make the reproductive but not the medical decision, her decision is never to have children, and sterilization appears to best implement her choice.

3) The retarded person is incompetent to make the reproductive decision and her parents seek authority to make the sterilization decision.

In choosing the kind of review process, interests in individual and family privacy as well as accuracy are relevant. See supra notes $120-37$ and accompanying text. 
verely impaired individual lacks an interest in having children; in such case there is no significant conflict of interest and a legal rule promoting family privacy and supporting parental authority will best protect her interests. Paternalistic judicial intervention should occur only when necessary to ensure that the retarded individual's rights are not violated.

It is for good reason that the law traditionally recognizes parents as decisionmakers for children. ${ }^{154}$ No one else knows the child as well or cares about her as much as do her parents. Although most adults no longer need their parents to make decisions for them, the rationale supporting parental authority can still be valid with respect to incompetent adults. ${ }^{155}$ For children and for many incompetent adults, substitution of a nonparent as decisionmaker is beneficial only if there is a serious conflict of interest between parent and child. ${ }^{156}$

154. There is a strong tradition of legal support for parents' authority to make decisions for their children and to generally direct their upbringing. The Supreme Court has recognized the constitutional status of the interest in family privacy, and has upheld parental authority against state intervention in several decisions. See Wisconsin v. Yoder, 406 U.S. 205, 234 (1972) (right of Amish parents to withdraw children from school at age 14, though legal minimum age was 16); Pierce v. Society of Sisters, 268 U.S. 510, 534 (1925) (statute requiring that all children be sent to public schools unreasonably interfered with the "liberty of parents and guardians to direct the upbringing and education of children under their control"); Meyer v. Nebraska, 262 U.S. 390, 399 (1923) (statute forbidding the teaching of foreign languages before the eighth grade unreasonably interfered with the right to "establish a home and bring up children").

The state may intervene to protect children if the parents' decisions or conduct threatens harm to the child. See Prince v. Massachusetts, 321 U.S. 158, 166 (1944) (statute prohibiting minor from selling newspapers and prohibiting adult from furnishing minor with newspapers did not infringe fourteenth amendment protected liberty). The state's parens patriae interest in the welfare of children supports state intervention in cases of abuse and neglect.

There has been a considerable amount of scholarly commentary on the tension between family privacy and the state's interest in protecting children. See J. Goldstein, A. Freud \& J. Solnit, Before the Best Interests of the Child 28-133 (1979); R. MNOoKin, ChILd, FAMILy and STATE 29-64 (1978); Wald, Children's Rights: A Framework for Analysis, 12 U.C. Davis L. Rev. 225, 281 (1979). In the first half of this century the rise of the juvenile court system and social work movement created enthusiasm for state intervention to protect children. See generally M. LEVINE \& A. Levine, A Social. History of Helping Services $46-47$ (1970); A. Pi.att, The Child SavERS: THE INVENTION OF DELINQUENCY 45 (1977). But modern commentators have challenged the notion that children benefit when the state intervenes to protect them from their parents. See J. Goi.dstein, A. Freud \& J. Solnit, supra, at 9; Chambers, The "Legalization" of the Family: Toward a Policy of Supportive Neutrality. 18 U. Mich. J.L. Ref. 805, 817 (1985); Mnookin, Foster Care-In Whose Best Interest?, 43 Harv. Educ. Rev. 599, 622-26 (1973); Wald, 27 STAN. L. REv. 985, 987-89 (1975).

In recent years there has also been a recognition that the child herself may have an interest in controlling decisions, particularly reproductive decisions, that affect her life. Sce supra note 104. Thus, legal policy dealing with children may on some issues have to balance three interests: the state's parens patriae interest, the parents' (and child's) interest in family privacy, and the child's autonomy interest. See Garvey, Child, Parent. State and the Due Process Clause: An Essay on the Supreme Court's Most Recent Work, 51 S. CAI.. L. Ri:V. 769 (1978).

155. See infra notes 171-72 and accompanying text.

156. See infira notes 160-69 and accompanying text. 
1. Examining the Conflict of Interest. A constricted range of interests are at stake for a severely disabled person when her parents propose sterilization. This person will never function as a parent. Meaningful decisions about reproduction or about the medical means for avoiding pregnancy are beyond her capabilities. Thus, no interest in selfdetermination or in reproduction is potentially in conflict with her parents' interest in seeking sterilization. The severely retarded person does, however, have an interest in avoiding pregnancy. The physical strain of pregnancy and the discomfort, pain, and risk of childbirth are burdens to be avoided when the individual cannot enjoy or adequately care for a baby. Indeed, when a severely retarded young woman is at risk of becoming pregnant, few question either her interest in avoiding pregnancy or her parents' authority to protect her by employing some form of contraception. Beyond this, the severely impaired person has an interest in avoiding unnecessary medical risk; any surgical or medical procedures should be beneficial to her, and risk, discomfort, and intrusiveness should be minimized. She also has a right to be treated with dignity. Her objections should be taken seriously, and her privacy should not be unduly sacrificed. Finally, her interest in family functioning will often be implicated because sterilization of the severely retarded person can lighten the burden of responsibility on her parents or contribute to their determination to continue to care for her at home.

For persons who will never have an interest in reproduction, a substantial conflict of interest with their parents is likely only if the parents seek to have a hysterectomy performed. The convenience to parents of avoiding menstrual hygiene care may clash with the child's interest in avoiding the substantial risk and intrusiveness that attends this surgical procedure. If the parents propose a less intrusive form of sterilization for their severely impaired child, no significant conflict of interest is apparent. Indeed, this child and her parents have a mutual interest in avoiding the child's pregnancy and promoting family stability. Furthermore, the child's interest in minimizing medical risk is served as well, or nearly as well, by sterilization as it would be by alternative contraceptive options.

\section{The Costs of Withholding Parental Authority. The rigorous} procedural and substantive requirements under current law impose formidable costs on the family, in terms of money, time expended, and psychological stress. In most states, parents seeking sterilization will have to hire an attorney to pursue their objective. ${ }^{157}$ They may have to pay for

157. Most parents will need the assistance of a lawyer to file the petition and present supporting evidence. Although most laws provide for the appointment of a guardian ad litem for the child. none provides the parent with legal assistance. 
mental health evaluations and will often be forced to miss time from work. Furthermore, to the extent that the procedure imposes burdensome requirements and particularly if it has an adversarial character, it will predictably create greater tension within a family unit already subject to considerable stress.

Many parents who have struggled with the burden of caring for a severely disabled child will understandably resent a judicial proceeding that is premised on the notions that they are pursuing their own interest in seeking their child's sterilization and that a judge can better decide what is best for their child. If sterilization is denied because rigorous substantive requirements are not met, the parents' frustration can have a disruptive effect on their ability to care for the child. For some parents, fear that their child may become pregnant will severely strain their ability to cope with the difficulties of caring for a retarded child. Sterilization may be a means of preserving family functioning by helping parents meet their responsibilities; they may view it as an alternative to institutionalization or foster care. ${ }^{158}$

For severely impaired individuals whose parents propose a nonintrusive type of sterilization, judicial scrutiny serves only one useful purpose. A check is needed to ensure that the individual actually lacks any reproductive autonomy interest. It is possible to accomplish this objective with less cost to the family and the disabled person than is the case under current law. Indeed, as I shall argue below, some individuals can receive adequate protection with no judicial proceeding.

Along with costly procedural protections, current law imposes burdensome substantive barriers. These include requirements that no temporary form of contraception be workable, that the individual be currently engaging in sexual activity, and that sterilization be necessary to preserve the physical or mental health of the individual. These criteria are based on the assumption that a significant reproductive interest is threatened by the sterilization initiative. As applied to a category of persons without this interest, these requirements become superfluous and serve to thwart parental efforts without offering a corresponding benefit to the child. Thus, they can ultimately do more harm than good to the disabled person.

The preservation of family functioning and the minimization of stress are as important to the severely disabled person as to her parents. To the extent that the procedural and substantive requirements under

158. In cases evaluated at the Forensic Psychiatry Clinic at the University of Virginia, parents often expressed frustration and resentment at the expense and complex legal requirements for sterilization and occasionally have said that they would give up custody if sterilization were not possible. 
current law place additional stress on the family, they represent a cost to the subject of the sterilization initiative as well as to her parents.

\section{The Constitutional Parameters: Parental Authority and Chil-} dren's Reproductive Rights. The traditional legal authority of parents to make medical decisions for their children rests, in part, on a presumption that parents are motivated to promote their children's interests. If parental authority conflicts with an important interest of the child's, it should be withdrawn.

Courts and commentators, emphasizing the potential for a conflict of interest, have suggested that the retarded person's constitutional interest in reproductive privacy is not protected unless parental authority is withdrawn. ${ }^{159}$ It might be thought that the autonomy model violates this interest by allowing parents to make the sterilization decision for severely impaired children. Yet the critical interest in reproductive autonomy that mandates protection is absent in these cases and consequently there is no substantial ground for withdrawal of parental authority.

The Supreme Court has examined constitutional challenges to parental authority to make sensitive medical decisions for the child in two contexts-abortion and psychiatric hospitalization. In both areas, an important interest of the child may conflict with the parents' interest, and the presumption underlying parental authority-that parents will act in their child's best interest-is called into question. These cases are often pointed to by those who support withdrawal of parental authority in the sterilization context. However, an examination of the Court's analysis in the abortion and psychiatric hospitalization cases supports the contention that a constitutional challenge to parental authority to make the decision to sterilize a severely retarded child has little merit.

a. The Abortion Rights of Minors. The mature minor who seeks an abortion is making a meaningful reproductive choice that should be respected. Indeed, under my analysis, this recognition should not be contingent on her capacity to give informed consent to the medical procedure. Unless undue coercion is involved, her decision not to continue the pregnancy warrants the withdrawal of traditional parental authority. ${ }^{160}$

The abortion cases present a situation in which parents and child are in actual disagreement over the decision to abort, or in which the child is

159. See In re C.D.M., 627 P.2d 607, 614 (Alaska 1981); In re A.W., 637 P.2d 366, 370 (Colo. 1981); In re Grady, 85 N.J. 235, 264, 426 A.2d 467, 482 (1981); Murdock, supra note 10, at 932-34; Price \& Burt, supra note 25, at 69-70; Sherlock \& Sherlock, supra note 10, at 955.

160. A determination that she is too immature to make this decision may lead to the paradoxical result that her pregnancy should continue and the immature minor should become a mother. 
reluctant to consult her parents because she fears conflict. ${ }^{161}$ Furthermore, other interests besides health are at stake here and a congruence of interests between parent and child cannot be presumed. Therefore, the traditional presumption that parents will make medical decisions that promote their child's health must be set aside. It is the possible conflict of interest and probable conflict in fact between parent and child over a matter of critical importance to the child's life, as well as the assumption that the child is mature and making a rational choice, that justifies the withdrawal of parental authority.

In Planned Parenthood v. Danforth, ${ }^{162}$ the Court rejected the notion that absolute parental authority over a minor's abortion decision could be justified on the basis of an interest in preserving family stability:

It is difficult ... to conclude that providing a parent with absolute power to overrule a determination, made by the physician and his minor patient, to terminate the patient's pregnancy will strengthen the family unit. Neither is it likely that such veto power will enhance parental authority ... where the minor and the nonconsenting parent are so fundamentally in conflict and the very existence of the pregnancy already has fractured the family structure. ${ }^{163}$

A mildly disabled individual whose parents seek sterilization has an interest in making autonomous reproductive choices similar to that of a minor contemplating abortion. However, the analogy is not applicable to a retarded person who is so disabled that she lacks the ability to make the decision. These cases typically arise in a context that differs substantially from that of the teenager seeking an abortion without her parents' knowledge. If the child is significantly retarded, it is probable that her parents have initiated the procedure; the child's response is likely to be incomprehension or assent. Since the child has no interest in reproduction, there is no potential conflict of interest with her parents unless an intrusive sterilization procedure is proposed. The overt, or at least implicit, family conflict inherent in the abortion context is absent here. Thus, the sterilization decision is not made in the context of the "fractured" family structure discerned by the Court in Danforth. Indeed, the sterilization initiative might represent an effort by the parents to preserve

161. In a study of 1170 teenagers who obtained abortions, the Alan Guttmacher Institute found that approximately 55\% reported that their parents were aware of their decision to abort. Of those whose parents did not know, $23 \%$ said they would not have gone to an abortion clinic if they had been required to tell their parents; $40 \%$ of these said they would have obtained an illegal abortion. See Torres, Forrest \& Eisman, Telling Parents: Clinic Policies and Adolescents' Use of Family Planning and Abortion Services, 12 FAM. Plan. PERSP. 284 (1980). Some studies have suggested that minors overestimate the negativity of parents' reactions. See Furstenburg, The Social Consequences of Teenage Parenthood, 8 FAM. Plan. PERSP. 148 (1976). Nonetheless, fears can affect the minor's behavior.

162. 428 U.S. 52 (1976).

163. Id. at 75 . 
family functioning and thereby continue to meet their responsibilities toward their retarded child, an objective that surely promotes the interest of the retarded person.

b. The Analogy to Psychiatric Hospitalization. The efforts of parents to obtain sterilization for their retarded child are also analogous to the efforts of parents seeking to have their reluctant child committed to a psychiatric hospital. Involuntary psychiatric hospitalization is a coercive medical intervention and the interests of the parents can conflict with a constitutionally protected liberty interest held by the resisting child. In Parham v. J.R., ${ }^{164}$ however, the Supreme Court upheld a Georgia statute that authorized parents to place their minor children in psychiatric hospitals, refusing to require a "formal adversary pre-admission hearing" to protect the child's liberty interest. ${ }^{165}$ The Court stated that "[t]he fact that a child may balk at hospitalization . . . does not diminish the parents' authority to decide what is best for the child." 166

As Justice Brennan pointed out in his dissenting opinion in Parham, a significant conflict of interest is possible in this situation. The parents' decision to hospitalize might be motivated by a desire to relieve the family of the burden of a disruptive child. Justice Brennan argued that the child whose parents seek to surrender custody to a state mental institution has, in effect, been "ousted from his family." 167 The hospital may serve as a "dumping ground" for children whose parents either cannot or will not continue to care for them. ${ }^{168}$ Policy reasons for maintaining parental authority-supporting the preservation of the family unit and protecting family privacy-are less compelling in this situation.

The parents' decision to sterilize can pose a greater threat to a potentially competent child's constitutionally protected interests than does the decision to hospitalize; sterilization is permanent while psychiatric hospitalization may be of limited duration. However, if the child is not potentially capable of reproductive choice, she is less at risk than the child for whom hospitalization is sought. Parents seeking sterilization are not trying to "dump" their retarded child. Their initiative may well

164. 442 U.S. 584 (1979). For a critical analysis of this case, see Melton, Family and Mental Hospital as Myths: Civil Commitment of Minors, in Children, Mental Health and the Law 1983, at 151 (1983).

165. Parham, 442 U.S. at 603.

166. Id. at 604 .

167. Id. at 631 (Brennan, J., dissenting).

168. Id. at 629 ("The National Institute of Mental Health recently found that only $36 \%$ of patients below age 20 who were confined in St. Elizabeth's Hospital actually required such hospitalization.”). The literature does not support the majority's positive view of state mental hospitals and their potential benefits to the unwilling minor whose parents seek her admission. See Melton, supra note 164 , at $158-59$. 
be an effort to facilitate her continued care at home. Thus, potential conflicts of interest would seem less probable in this situation than when psychiatric hospitalization is proposed.

Preserving parental authority to make the sterilization decision for severely impaired children does not inherently violate a constitutionally protected interest. The critical reproductive interest that mandates protection in abortion cases and in sterilization cases involving less disabled persons is absent. Furthermore, the potential for conflict would appear to be less threatening than when psychiatric hospitalization is sought by parents-a decision that the Court has found may be appropriately made by parents and doctors without judicial intervention. ${ }^{169}$ Thus, some retention of parental authority in these cases should pass constitutional muster.

The interest of both parent and child in family privacy has itself been accorded constitutional protection on both libertarian and utilitarian grounds. ${ }^{170}$ Sound legal policy limits state intervention in family affairs to situations in which there is a real threat of harm to the child or in which there is a significant conflict of interest. A parental decision to sterilize a severely retarded child for contraceptive purposes by a nonintrusive procedure falls within the traditional legal and constitutional protections. Expansive paternalistic intervention by the state that does not protect the child is not a valid exercise of parens patriae authority.

Parents who seek sterilization of adult children may seem less clearly suitable as decisionmakers. Traditional parental authority ex-

169. The Georgia law upheld in Parham required independent review by the medical director of the facility of the appropriateness of the admission. What the Court rejected was the need for formal adversary hearings, which the Court characterized as "time-consuming procedural minuets." Parham, 442 U.S. at 605 . The Court found that requiring a hearing would be disruptive to the family and would discourage parents from seeking needed treatment. $I d$. at 605 .

170. See supra note 154 . Libertarian support for family privacy is the extension to the family unit of a belief in the primacy of the individual under the due process clause of the fourteenth amendment. Within the family, parents are the natural decisionmakers for their minor children. For an analysis of parental authority to make medical decisions for children, see Goldstein, Medical Care for the Child at Risk: On State Supervention of Parental Authority, 86 YALE L.J. 645 (1977).

The utilitarian position emphasizes not so much the inviolability of the parents' liberty interest as it does the insubstantial quality of the state interest that justifies intervention. The proposition that children are generally better off if the state does not interfere with the family is supported by three arguments. First, it is uncertain when parental conduct will harm children. Second, the intervention may be harmful because it disrupts the child's life and family ties. Finally, the alternative placement offered by the state may be harmful to the child because it is unclear that children benefit from foster-care placements. In sum, family privacy should receive legal support because parens patriae intervention may do more harm than good. Compared with the libertarian, the utilitarian more readily accepts increased state intervention if it is demonstrably beneficial to children. Compare J. Goldstein, A. Freud, A. Solnit \& S. Goldstein, In the Best Interests of the CHILD (1986) (libertarian approach) with Mnookin, supra note 154 (utilitarian approach). 
tends only to minors, unless a guardianship has been established. ${ }^{171}$ Furthermore, the interest in family continuity is often less compelling, since most adult children can be expected to leave home at some point. ${ }^{172}$ Nonetheless, parental authority should be maintained in cases involving severely retarded adults who have been cared for by parents since childhood. One can assume that these parents know their child better than anyone else and that they are most concerned with her interests. If a surrogate is needed, there is no reason to believe that a court will make better decisions than parents in cases in which no apparent conflict of interest exists. Even if the disabled individual may eventually leave home to live more independently - an objective which loving parents might promote-the parents are still the best decisionmakers for their incompetent child.

4. Safeguarding Against Erroneous Decisions. The primary barrier to recognizing parental authority to make sterilization decisions is the concern that person in question will be erroneously classified as lacking an interest in reproductive autonomy. The principal justification for judicial intervention is that it reduces error and provides optimal protection of that interest. Although this protective approach imposes significant costs on an already burdened family, it may seem necessary to ensure that an accurate evaluation of the individual's capacities is made.

Under the autonomy model, there are two ways to reduce error without unduly sacrificing of family privacy. The first, discussed above, is to ensure that determinations regarding competency are made by an expert. ${ }^{173}$ The second involves linking the scope of judicial intervention to the level of disability. Error can be reduced by increasing the level of scrutiny and procedural protection in cases in which there exists an enhanced possibility that the individual has a reproductive interest.

Mentally disabled persons who will require lifelong care clearly lack the capacity to care for a child. They also have a greater interest in family continuity and stability than do those who are less disabled. Thus, only minimal procedural requirements are desirable. If a reliable clinical evaluation shows that the person lacks the capacity to care for herself, little risk is created by avoiding a judicial proceeding altogether and permitting the sterilization to be performed upon parental request and authorization.

171. See supra notes 101-02 and accompanying text.

172. An objective for many retarded adults is to live in a home or apartment with a few other disabled persons with minimal assistance and supervision. See E. Schul.man, supra note 26 , at 65.

173. See supra note 151 and accompanying text. 
In the case of a less disabled person who is potentially capable of caring for herself, but who clearly lacks an interest in reproduction, judicial review is desirable if the procedural costs to the individual and her family are outweighed by the potential for reducing error. Alternatively, procedural costs might be reduced without unduly sacrificing accuracy by using a less formal review forum similar to a hospital ethics committee. ${ }^{174}$ Such a committee could undertake nonadversarial review of the expert's evaluation to ensure that it is competent, independent, and based on all relevant information. The committee could consult with other experts or with the parents. Such a nonjudicial review mechanism would protect family privacy and stability to a greater degree than would a judicial proceeding.

If the disability is less severe, the possibility of underestimating the interest in reproductive choice becomes greater, and the costs of procedural protections become more acceptable. Thus, if the findings of the expert raise any ambiguity about the individual's potential interest in reproductive choice, judicial review is warranted.

174. Institutional Review Boards (IRBs) review proposals for research involving human subjects with the objective of protecting the subjects from undue harm and ensuring informed consent. Federal regulations require IRB approval of virtually all federally funded research. See 45 C.F.R. $\S 46.103$ (1985). The committee must be diverse in membership and must include members from diverse disciplines and different medical specialties. See id. § 46.107. See generally N. Hershey \& R. Miller, Human Experimentation and the Law 47 (1976); R. Levine, Ethics and Regulation of Clinical ReSEARCH 321-63 (1986). For an analysis of ethics committees and the law, see Capron, Legal Perspectives on Institutional Ethics Committees, 11 J.C. \& U.L. 417 (1985).

Ethics committees have been established in other areas to review or make recommendations regarding medical decisions. For example, Infant Care Review Committees (ICRCs) assist in decisionmaking about critically ill newborns. The current applicable HHS regulation recommends that any health care provider receiving federal assistance establish an ICRC. 45 C.F.R. $\S 84.55$ (a) (1985). The regulation includes an advisory model making the committee responsible for: (1) recommending institutional policies concerning the withholding or withdrawal of life-sustaining treatment for seriously ill newborns, (2) providing advice when life-sustaining treatment is in question, and (3) reviewing situations where life-sustaining medical or surgical treatment has been withdrawn. HHS recommends that the IRCRs include members from varied backgrounds such as doctors, nurses, hospital administrators, lawyers, disability group representatives, and community members. HHS also recommends that a medical staff member serve as chairperson. Id. $\S 84.55(\mathrm{f})$. In Bowen v. American Hosp. Ass'n, 106 S. Ct. 2101 (1986), the Supreme Court upheld parental authority to elect to withhold life-sustaining treatment from seriously ill newborns and invalidated four subsections of section 84.55 , including the subsection that required health care institutions receiving federal funds to post notice that treatment could not be withheld from handicapped infants solely because of their handicap. 45 C.F.R. $\$ 84.55$ (b) (1985). Subsections (a) and (f) were not challenged, however. See Bowen, 106 S. Ct. at 2106 n.4. The American Academy of Pediatrics adopted guidelines for Hospital Infant Bioethics Committees in April 1984. See American Academy of Pediatrics Guidelines for Infant Bioethics Committees, 11 J.C. \& U.L. 433 (1985).

A sterilization-review committee might include mental retardation experts. gynecologists, psychologists, attorneys, parents, and mental disability advocates. The committee should review the professional assessment of competency, not decide whether sterilization is in the individual's best interest. In performing its review, it may be necessary for the committee to speak directly with the individual and her parents, although this may have significant privacy costs. See supra notes 129-30. 
Mandatory judicial review may also be indicated if the person protests the sterilization in any meaningful way, regardless of her level of disability. ${ }^{175}$ The incompetent person's protest should not be a bar to her parents' decision. Nonetheless, it would justify mandatory judicial scrutiny of her lack of competency.

The autonomy model contemplates a considerably more limited judicial role than does the paternalism model. Decisions made outside the judicial process will often better serve the interests of the disabled person. For the seriously disabled individual, family privacy and stability will be promoted by as simple a review process as is consistent with an accurate assessment of her interests. For the clearly competent or potentially competent person, judicial review should only be triggered, if at all, when sterilization is proposed as a means to implement the choice to avoid pregnancy by a person who lacks the capacity to make the medical decision.

There are only two situations under the autonomy model in which it is appropriate for courts to actually decide whether sterilization is in the best interest of the incompetent disabled person. ${ }^{176}$ The first is when the parents seek a hysterectomy for their child; the second is when the parents who are seeking sterilization of their child have not assumed primary responsibility for her care. In both instances, the autonomy model indicates that the interests of the individual are such that the parents can no longer be presumed to be the best decisionmaker.

a. The Special Case of Hysterectomy. Judicial scrutiny is appropriate if a hysterectomy is sought because this operation subjects the individual to major surgery that is not required for gynecological reasons. ${ }^{177}$ Parents may seek a hysterectomy for a number of reasons. Usually they desire to end their daughter's menstrual cycles because they believe that she is unable to manage menstrual hygiene tasks. Some parents may seek a hysterectomy because their daughter experiences physical or psychological problems during menstruation. ${ }^{178}$ Finally, parents may propose a

175. Some threshold of understanding may be required before judicial review is triggered; a young child or seriously retarded person may protest a medical procedure without comprehension. The review is a mechanism to ensure that the individual has not been wrongly classified as one who lacks reproductive interests. Responding to the protest by invoking the judicial process signifies that the individual's objection is respected. For an analysis of the importance of process to human dignity, see Mashaw, Administrative Due Process: The Quest for a Dignitary Theory, 61 B.U.L. REV. 885 (1981).

176. See supra notes $154-56$ and accompanying text.

177. See supra note 126 and accompanying text.

178. Parents often report that their retarded daughters are unduly distressed during their periods and are consequently difficult to manage at home and at school. Some may even react self-destructively. Thus, in some families, the girl's period may cause considerable disruption each month. In 
hysterectomy for their own and their daughter's convenience, even if the child experiences few problems with menstruation. They may reason that since their disabled daughter will never want to have children, a hysterectomy is a desirable way to avoid the monthly "hassle" of menstruation. ${ }^{179}$ In light of the significant medical risks involved, few normal women would consider undergoing a hysterectomy purely for convenience. Therefore, a decision to subject an incompetent individual to this procedure cannot be justified on such relatively minor grounds.

The important inquiry when a hysterectomy is proposed is whether the problems associated with the menstrual periods substantially interfere with the individual's functioning and well-being and, if they do, whether they are subject to remediation. Parents (and even teachers) often underestimate the potential for training mentally disabled girls to manage menstrual hygiene tasks and thus may exaggerate the burden. ${ }^{180}$

\section{b. Petitioning Parents Who Have Relinquished Care of Their Child.} The case for supporting parental authority to make the sterilization decision is considerably weakened if the parents have put the child in an institution or surrendered custody to a state agency. These parents may lack the intimate concern for and knowledge about the child which, in the case of custodial parents, supports the presumption that the parents will act to promote the child's interest. Furthermore, there is less reason to support the authority of parents who have not assumed the burdensome responsibility of care for the disabled child. Moreover, some parents in this situation may petition for sterilization because of pressure from the facility where the child resides. Finally, the retarded person's interest in family continuity and harmony is not great in this context.

Although there is less reason to support parental authority in these cases, it does not necessarily follow that a court will always be a better decisionmaker. A court, however, is less likely than the parents to be subject to external pressures or be influenced by a conflict of interest in this context. A judicial decisionmaker is arguably preferable because there is no compelling argument that the child's interest is better protected by preserving parental authority. The court should make the decision that a reasonable and concerned parent would make to promote the

one Forensic Psychiatry Clinic case, E.'s mother reported that she was required to miss three or four days of work each month when her severely retarded daughter had her period because E. 's teacher and sitter found E.'s inability to manage menstrual hygiene tasks so offensive that they urged E. 's mother to keep her at home during these times.

179. In several of the Forensic Psychiatry Clinic cases, doctors advised parents to seek hysterectomy despite the absence of serious problems. See supra note 126 and accompanying text. Parents sometimes seemed unaware that hysterectomy is major surgery.

180. See supra note 127. 
child's welfare. Considerations may include the likelihood of sexual activity and risk of pregnancy, the relative benefits to this individual of alternative forms of contraception, and the individual's expressed or anticipated preferences.

\section{CONCLUSION}

The undisputed objective of sterilization law is to promote decisions that reflect the interests of the disabled person. The autonomy model proposed in this article offers a more accurate and precise definition of these interests than does the paternalism model that forms the foundation of current law. The paternalism model limits the mentally disabled person's freedom through the erection of formidable barriers to sterilization. These barriers are justified by a strong presumption that the individual has a pervasive interest, not in autonomy, but in procreation. By clarifying the substantive interest in procreation as an interest in producing a child to rear, the autonomy model promotes a direct examination of whether the person in fact has this interest. If the person cannot rear a child, she lacks this interest and the law should take into account those interests that she retains. These residual interests include interests in optimal medical decisions, in human dignity and privacy, and in family stability.

The desire to correct the abuses of the past is admirable. We should only take care that in pursuing this goal, we do not create a new set of problems for the future. In contrast to current law, the autonomy model accords substantial deference to personal and family autonomy. The model reveals that the law's objectives are best met by leaving the sterilization decision to the retarded person who is competent to make her own reproductive choices, with only as much intervention as is necessary to facilitate her decisions. For retarded persons who cannot make their own decisions, parents-not courts-are the best surrogates. 